\title{
Onverpersoonlikingstrategieë in Afrikaans Impersonalisation strategies in Afrikaans
}

\section{Adri Breed}

Vakgroep Afrikaans en Nederlands

Skool vir Tale

Noordwes-Universiteit

Potchefstroom, Suid-Afrika

E-pos: adri.breed@nwu.ac.za

\section{Dr Daniël van Olmen}

Department: Linguistics and English Language

Lancaster University, United Kingdom

E-pos: d.vanolmen@lancaster.ac.uk

\section{Jo-Ann Chan}

Vakgroep Grafiese Ontwerp

Skool vir kommunikasiekunde

Noordwes-Universiteit

Potchefstroom, Suid-Afrika

E-pos: jo-ann@nwulettere.co.za

Tel: 0182994051

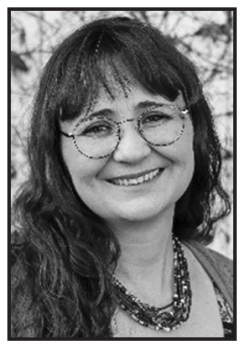

Adri Breed

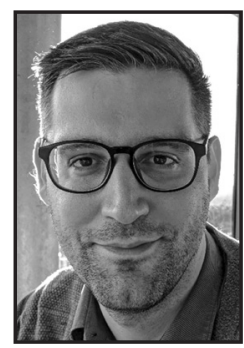

Daniël van Olmen

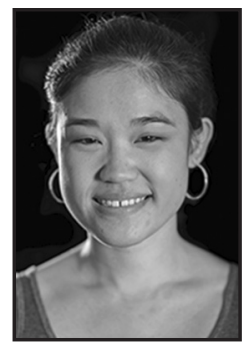

Jo-Ann Chan
AdRI BREED is 'n NRF-gegradeerde medeprofessor in Afrikaanse beskrywende taalkunde aan die Noordwes-Universiteit. Sy spesialiseer in Afrikaanse sintaksis en semantiek, met 'n spesiale fokus op die grammatikalisering van tempus- en aspekkonstruksies in Afrikaans en ander WesGermaanse tale. Sy het vyf grade aan die NWU voltooi, naamlik Bedryfskommunikasie (BBK, 2005), Teologie met Tale (BTh Tale, 2005), 'n Honneurs in Afrikaanse Taalkunde (BA Hons, 2007), 'n Meestersgraad in Afrikaanse letterkunde (MA, 2007), en 'n doktorsgraad in Afrikaanse Taalkunde (PhD, 2012). Tydens haar doktorale studies spandeer sy ongeveer tien maande aan Antwerpen Universiteit in België as medewerker van die Center for Grammar, Cognition and Typology. Sy is voorsitter van die Potchefstroomkampus se Vakgroep Afrikaans en Nederlands. Sy dien op die bestuur van die Suider-Afrikaanse
ADRI BREED is an NRF-rated associate professor of Afrikaans descriptive linguistics at the NorthWest University's Potchefstroom Campus. She specialises in syntax and semantics, with a particular focus on the grammaticalisation of tense and aspect constructions in Afrikaans and Dutch. She completed five degrees at the NWU, namely a degree in Business Communication (BBk, 2005), a degree in Theology with languages (BTh Languages, 2005), an Honours degree in Afrikaans Linguistics (BA Hons, 2007), a Master's degree in Afrikaans Literature (MA, 2007) and a $\mathrm{PhD}$ in Afrikaans Linguistics in 2012. During her doctoral studies, she spent roughly ten months at the University of Antwerp, Belgium as a research member of the UA's Center for Grammar, Cognition and Typology. She is subject head of the Subject Group: Afrikaans and Dutch Studies on the Potchefstroom Campus. She is vice-chair 
Vereniging vir Neerlandistiek, en is lid van PanSAT se Afrikaanse Nasionale Taalliggaam (ANLB). Sy is een van die outeurs en moderators van Taalportaal (www.Taalportaal.org), en ook eindredakteur van die Virtuele Instituut vir Afrikaans (VivA) se Taalonderrigportaal.

Daniël van OLMEN is 'n medeprofessor aan die Universiteit van Lancaster (Verenigde Koninkryk). Sy navorsing fokus op tempus, modus, modaliteit, pragmatiese merkers, onbepaalde konstruksies en ontkenning vanuit die perspektiewe van kontrastiewe taalkunde, taalkundige tipologie, historiese taalkunde, arealiteit en korpuslinguistiek. Hy het in internasionale tydskrifte gepubliseer oor onder andere "menslike onpersoonlike voornaamwoorde" in Wes-Germaanse tale, konstruksies van verwyt in die tale van Europa en prohibitiewe ontkenningskonstruksies in die tale van die wêreld. Hy tree as mederedakteur op van akademiese boeke wat handel oor grammatikalisering, taalkundige variasie en imperatiewe en direktiewe strategiee. Hy is tans een van die twee hoofredakteurs van De Gruyter se Trends in Linguistics -Studies and Monographs book series (https://www.degruyter.com/ view/serial/TILSM-B).

Jo-Ann Chan is 'n dosent aan die NoordwesUniversiteit (NWU). Sy het 'n BA-graad (2013) en praktykgebaseerde Meestersgraad (2017) in grafiese ontwerp aan die NWU voltooi. Haar Meestersgraadnavorsingsprojek, naamlik Visualising the voices of Redan: an experimental application of forensic anthropology and narrative identity to a disappearing landscape het haar belangstelling in kunstenaarsboeke, illustrasie en interdissiplinêre praktyke ontwikkel. Saam met ontwerpspedagogiek vir tersiêre onderrig, vorm hierdie belangstellings ook haar navorsingsfokusse. Sy is aktief in die Suid-Afrikaanse kunsgemeenskap as 'n vryskutillustreerder en ontwerper, onafhanklike kunstenaar en lid van die $A B C$ kunskollektief. Sy het al aan verskeie plaaslike groepuitstallings deelgeneem, waar haar werk die oorvleueling tussen die visuele en taalkundige modaliteite ondersoek. In 2019 hou sy haar eerste solo-uitstalling by die Wits Origins Centre Museum in Johannesburg. of the South African Association for Dutch Studies (SAVN) and a managerial member of the Dutch Language Union's South African Northern Knowledge Network. She is a member of PanSALB's Afrikaans Language Body. Adri was one of the authors of Taalportaal - an international project constructing a comprehensive and authoritative scientific grammar website for Dutch, Frisian and Afrikaans. She is an associate editor for the ISI-accredited journal, South African Language and Applied Language Studies. Currently, she is the editor-in-chief for the Virtual Institute of Afrikaans' general Afrikaans grammar and language education portal.

DaniëL VAN Olmen is an associate professor at the University of Lancaster (United Kingdom). His research focusses on tense, mode, modality, pragmatic markers, impersonal constructions and negation from the perspectives of contrastive linguistics, linguistic typology, historical linguistics, a-reality and corpus linguistics. He has published in international journals on human impersonal pronouns in West Germanic languages, constructions of resentment in the languages of Europe and prohibitive negation constructions in the languages of the world. He is the co-editor of academic books on grammaticalization, linguistic variation, and imperative and directive strategies. $\mathrm{He}$ is one of the editors of De Gruyter's Trends in Linguistics Studies and Monographs book series (https://www.degruyter.com/view/serial/ TILSM-B).

Jo-Ann Chan is a lecturer at the North-West University (NWU). She obtained a BA in 2013 and a practice-based MA in graphic design in 2017 - both from the NWU. Her MA project entitled Visualising the voices of Redan: an experimental application of forensic anthropology and narrative identity to a disappearing landscape developed her interest in artist's books, illustration, and interdisciplinary practices. Along with the pedagogy of design, these topics form her research focusses. She is an active member of the South African art community as a freelance illustrator and designer, independent artist, and member of the ABC art collective. She has participated in several art exhibitions where her work investigates the overlap between the visual and linguistic modalities. She gave her first solo exhibition at the Wits Origins Centre Museum in Johannesburg in 2019. 


\section{ABSTRACT}

\section{Impersonalisation strategies in Afrikaans}

In this article, we examine impersonal constructions in Afrikaans, i.e. constructions without a referential subject or, put differently, constructions where the (implicit) subject can be paraphrased as "people in general", "someone" or "some people". This topic has already received considerable attention in the literature but the focus has generally been on a limited number of strategies, such as human impersonal pronouns (e.g. mens leef net een keer "one only lives once") and the passive construction (e.g. my kar is gesteel "my car has been stolen"). In our view, this narrow focus in the literature is at least partly due to the limitations of the language-based methods (e.g. corpus studies and questionnaires) currently used in the research. These methods essentially facilitate a deductive approach by investigating a predetermined set of more or less established impersonal constructions.

The present study, by contrast, adopts a more open-ended approach in order to get a better sense of the range of possible strategies that speakers of Afrikaans can use in different impersonal contexts and of the constructions that they prefer to employ in those various impersonal uses. We therefore draw on a visual questionnaire with few linguistic cues. Each scene in this questionnaire depicts a particular impersonal context-based on the distinguishing criteria found in the existing semantic maps of the domain of impersonalisation (such as quantification, perspective and veridicality) and respondents are encouraged to provide a sentence that captures the situation. The questionnaire was published online, promoted via social media and completed by more than 400 respondents.

The findings show first of all that there exist numerous alternatives to the well-known strategies of impersonalisation. In addition to pronouns (e.g. jy "you” in wat gebeur as jy die knoppie druk? "what happens when you press that button?") and passives (e.g. is gepluk "were picked" in terwyl jy geslaap het, is al die appels gepluk "while you were asleep, all the apples were picked"), the types of constructions identified in our study include but are not restricted to: nouns with the meaning "people" and an extra evaluative connotation (e.g. morsjorse "litterbugs" in morsjorse het gister hier gesit en drink "litterbugs were drinking here yesterday"), the generic use of the imperative (e.g. onthou "remember" in onthou om altyd jou sitplekgordel vas te maak! "remember always to fasten your seat belt!"), nominalisations (e.g. koud kry "getting cold" in die winter is vir koud kry gemaak "winter is made for getting cold") and free-choice constructions (e.g. wie ook al "whoever" in wie ook al gister hier sokker gespeel het, het hul bal vergeet "whoever played soccer here yesterday forgot their ball").

Our results are furthermore suggestive of the impersonal constructions that are clearly favoured by speakers of Afrikaans. They indicate, for instance, that the established but still comparatively under-researched strategy of passivisation is used across all impersonal contexts and is even regularly preferred to the better-studied pronouns in certain uses (e.g. daar is al weer terreuraanvalle uitgevoer "terror attacks have again been carried out" instead of hulle het al weer terreuraanvalle uitgevoer "they have again carried out terror attacks"). Indefinite pronouns too are found to be among the most common constructions-especially, though not only, in contexts assuming the existence of a particular unidentified person responsible for some event (e.g. iemand "someone" in iemand het al die appels gepluk "someone has picked all the apples"). Nouns with the meaning "people", finally, also appear to be quite favoured by speakers of Afrikaans and they occur in a variety of impersonal uses, such as statements about people in general that do not, however, include the speaker or the addressee (e.g. mense "people" in in China eet mense rys "in China, people eat rice"). 
KEYWORDS: $\quad$ impersonal; impersonalisation; agensless passive; human impersonal pronouns; universal; existential; impersonalisation strategy

TREFWOORDE: onpersoonlik; onverpersoonliking; agenslose passief; menslike onpersoonlike voornaamwoord; universeel; eksistensieel; onverpersoonlikingstrategie.

\section{OPSOMMING}

Hierdie artikel ondersoek die verskillende strategieë wat Afrikaanse sprekers gebruik om aan te dui dat ' $n$ konstruksie onpersoonlik is. Onpersoonlike konstruksies is konstruksies waar die (soms implisiete) subjek geparafraseer kan word as "mense in die algemeen", "'n onbekende persoon" of "sommige mense". Hierdie onderwerp het al baie aandag in die taalkundeliteratuur gekry, maar die fokus was meestal op 'n beperkte aantal onverpersoonlikingstrategieë, soos die gebruik van persoonlike voornaamwoorde (bv. Jy leef net een keer), onbepaalde voornaamwoorde (byvoorbeeld Iemand het my beursie gesteel!) en passiewe konstruksies (byvoorbeeld My kar is gesteel). Volgens ons kan dié nou fokus in die literatuur toegeskryf word aan die feit dat die navorsingsmetodes (byvoorbeeld korpusstudies en vraelyste) wat tot op hede gebruik is om onverpersoonlikingstrategieë te ondersoek, navorsers slegs in staat stel om op deduktiewe wyse na die strategieë te kyk. Tot op hede is daar nog nie 'n studie uitgevoer om te bepaal i) watter verskillende moontlike onverpersoonlikingstrategieë deur Afrikaanse sprekers aangewend kan word nie, en ii) of daar bepaalde voorkeure vir sprekers bestaan oor watter strategieë om te gebruik in die verskillende en onderskeibare onpersoonlike kontekste. Hierdie ondersoek beantwoord hierdie twee vrae deur die resultate van 'n visuele vraelys - wat aan ongeveer 450 Afrikaanssprekende respondente gegee is om te beantwoord - te bestudeer.

\section{Kontekstualisering ${ }^{1}$}

Onpersoonlike konstruksies kan gedefinieer word as konstruksies wat geen referensiële subjek bevat nie (Malchukov \& Siewierska, 2015:20). Onpersoonlike konstruksies het dus óf i) geen grammatikale subjek nie, óf ii) die subjek wat wel in die sin aangetref word, verrig slegs 'n pleonastiese funksie. Die subjek (hetsy gemarkeerd of ongemarkeerd) is dus inderwaarheid semanties leeg (vergelyk Siewierska, 2008).

'n Subjek van 'n sin is met ander woorde onpersoonlik (semanties leeg) wanneer dit niereferensieel gebruik word, en nie na 'n gespesifiseerde persoon of groep persone verwys nie. Só 'n subjek kan geparafraseer word as “mense in die algemeen", “'n onbekende persoon” of "sommige mense".

Daar is hoofsaaklik twee niereferensiële kontekste waarin 'n subjek onpersoonlik aangewend word (vergelyk Gast \& van der Auwera, 2013). Eerstens is dit wanneer die subjek te generies is om na 'n spesifieke persoon of persone te verwys. Hierdie konteks word 'n universele onpersoonlike konteks genoem, en sinne 1 en 2 hier onder dien as voorbeelde. ${ }^{2}$

Die eerste afdelings van hierdie artikel, sluit baie sterk aan by die kontekstualisering en teoretisering wat in Breed et al. (2021) aangebied word. Die huidige publikasie lewer verslag van die resultaat van die vraelysontwerpproses wat in Breed et al. (2021) omskryf word. Aangesien die kontekstualisering en teoretiese raamwerk ook vir hierdie artikel relevant is, word dit hier ook tot dieselfde mate en omvang aangebied.

2 Alle voorbeeldsinne in hierdie artikel is geneem uit VivA Korpusportaal: Omvattend (VivA, 2020) of uit die vraelys se antwoorde. In sommige gevalle is sinne minimaal aangepas. Waar geskikte voorbeelde nie in die korpusportaal gevind is nie, is eie voorbeelde geskep. Eie voorbeelde word telkens aangedui. 
$1 \quad J y$ leef net een keer, maar as jy dit reg doen, is een keer genoeg.

2 Mens mag nie foto's neem in die grotte nie.

Die konteks in voorbeeld 1 betrek álle persone in die mensdom. Voorbeeld 2 het betrekking op alle persone wat relevant is tot die konteks, naamlik alle mense wat die grotte besoek. Mense wat nie die grotte besoek nie, word nie by die stelling ingesluit nie. Die sinsubjekte, naamlik $j y$ in $\sin 1$ en mens in sin 2, is dus in beide gevalle niereferensieel, aangesien dit 'n generiese of universele verwysing het na ongespesifiseerde persone.

Tweedens word 'n onpersoonlike subjek soms aangewend omdat die spreker nie na 'n spesifieke persoon kán of wíl verwys nie. Hierdie konteks word 'n eksistensiële onpersoonlike konteks genoem, en sinne 3 en 4 is voorbeelde hiervan.

3 Hulle sê trou is nie perdekoop nie.

$4 \quad$ Hulle het al weer jou ma se pos hier afgelewer, Elizabeth!

Die voornaamwoordelike subjek hulle in sin 3 verwys na 'n ongespesifiseerde groep mense wat op een of ander stadium 'n opinie oor die daad van trou uitgespreek het. Dit is egter nie vir die spreker moontlik om die presiese persone te identifiseer wat die uiting gemaak het nie. Eweneens word dieselfde voornaamwoord, hulle, in sin 4 gebruik om te verwys na die instelling of organisasie wat die pos afgelewer het. Die instansie is na alle waarskynlikheid bekend aan of afleibaar vir die spreker en die hoorder. Die spreker vind dit daarom nie nódig om die subjek op referensiële wyse te spesifiseer nie, aangesien dit uit die konteks duidelik is dat die subjek waarskynlik die Suid-Afrikaanse Poskantoor of 'n ander bekende koerierdiens is.

Daar is verskeie maniere waarop 'n Afrikaanse spreker 'n konstruksie onpersoonlik ${ }^{3}$ kan maak, byvoorbeeld deur gebruik te maak van persoonlike voornaamwoorde wat onpersoonlik aangewend word (geïllustreer in voorbeeldsinne 1 en 5), onbepaalde voornaamwoorde (soos in voorbeeldsin 6), sommige naamwoorde of naamwoordstukke (byvoorbeeld sinne 2 en 7), of passiefkonstruksies (voorbeeld 8).

5 Ons moet altyd ons medemens respekteer.

6 'n Motor het nader gery en iemand het my daaruit geskiet.

7 Die mense wil behoorlike rugby sien.

8 Die skool se naam is in 1946 verander na die Paul Roos-gimnasium.

Onpersoonlike konstruksies is ' $\mathrm{n}$ gewilde studieonderwerp in resente taalkundenavorsing. Vergelyk byvoorbeeld onder andere die navorsing van Kitagawa en Lehrer (1990), Luukka en Markkanen (1997), Egerland (2003), Hoekstra (2010), Siewierska en Papastathi (2011) en Gast en van der Auwera (2013). Ook in Afrikaans het onpersoonlike konstruksies heelwat aandag gekry die afgelope paar jaar, byvoorbeeld deur Kirsten (2016), Van Olmen en Breed (2018a; 2018b), Van Olmen, et al. (2019), Breed en Van Olmen (2021), Groenen (2021) en Fouché en Kapp (2020).

Die temas van hierdie genoemde navorsing - spesifiek ook die navorsing oor Afrikaanse onpersoonlike konstruksies - het egter byna uitsluitlik gefokus op voornaamwoordelike strategieë van onverpersoonliking. Slegs een Afrikaanse publikasie, naamlik Breed en Van

3 Die woord "onpersoonlik" het verskeie konnotasies in Afrikaans (Botha, 2019; Pharos, 2006). In hierdie artikel word die woord egter altyd gebruik om - binne konteks van beskrywende taalkunde - te verwys na gevalle waar die subjek nie op referensiële wyse na die 'n spesifieke persoon of groep persone verwys nie. 
Olmen (2021), betrek ook 'n ander moontlike onverpersoonlikingstrategie, te wete die passiefkonstruksie. Tot dusver is min inligting beskikbaar oor die ander moontlike strategieë van onverpersoonliking. Daar is byvoorbeeld nog nie vantevore 'n ondersoek geloods om i) te bepaal watter verskillende strategieë daar tot Afrikaanse sprekers se beskikking is om kontekste as onpersoonlik uit te druk nie, en ook nie ii) watter onverpersoonlikingstrategieë Afrikaanse sprekers verkies om bo ander strategieë te gebruik in verskillende onpersoonlike kontekste ${ }^{4}$ nie.

Hierdie tweeledige leemte geld egter nie net in Afrikaanse taalkunde nie, maar ook vir navorsing oor ander tale. Naas Siewierska (2008) se artikel, Ways of impersonalizing, blyk daar tot op hede nie juis bronne beskikbaar te wees wat ten doel het om aan te toon watter moontlike onverpersoonlikingstrategieë daar vir taalsprekers beskikbaar is nie, asook nie wat die spesifieke voorkeuronverpersoonlikingstrategieë in die verskillende onpersoonlike kontekste is nie. Boonop lyk dit nie asof Siewierska poog om 'n omvattende lys van moontlike onverpersoonlikingstrategieë aan te bied nie, maar eerder op eksemplariese wyse te illustreer hoe verskillende tale onpersoonlike betekenis kan uitdruk. Hoewel sy 'n aantal strategieë aantoon wat nie algemeen in die literatuur oor onpersoonlike konstruksies aangebied of bespreek word nie, is haar voorbeelde hoofsaaklik gebaseer op beskikbare grammatikas en die insette van eerstetaalsprekers van verskillende tale. In haar artikel word dus geen sistematiese of uitgebreide analise van 'n taaldatastel gemaak nie.

'n Moontlike rede vir die gebrek aan beskikbare navorsing oor moontlike onverpersoonlikingstrategieë, is die feit dat dit regtig uitdagend is om hierdie fenomeen in taalgebruik te ondersoek. Tot op hede is hoofsaaklik drie metodes gebruik om onpersoonlike konstruksies in spesifieke tale te bestudeer of te bepaal: eerstens word beskikbare grammatikas geraadpleeg of informele vrae aan eerstetaalsprekende taalkundiges gestel (bv. Siewierska, 2011; Gast \& van der Auwera, 2013), tweedens word korpusse ondersoek, (bv. Marin-Arrese, Caro \& Becerril, 2001; Coussé \& van der Auwera, 2012), en derdens word sprekers van 'n bepaalde taal gewerf om 'n taalkundige vraelys in te vul (bv. Siewierska, 2008; Garcia, Sallandre \& L'Huillier, 2018). Breed et al. (2021) dui omvattend aan waarom hierdie metodes nie voldoende is om die verskillende moontlike strategieë van onverpersoonliking te ondersoek nie. Opsommend kan hier genoem word i) dat ál die metodes onpersoonlike konstruksies op deduktiewe wyse ondersoek, en dus aanneem dat alle moontlike onverpersoonlikingstrategieë reeds aan ons bekend is, ii) dat spesifiek 'n korpusondersoek na onverpersoonlikingstrategieë nie ideaal is nie, aangesien nie alle onpersoonlike kontekste frekwent in taalgebruik voorkom nie, en dus nie lei tot goeie taalkundige afleidings oor onverspersoonlikingstrategieë nie, en iii) dat die vraelyste wat tot op hede in navorsing oor onpersoonlike konstruksies gebruik is, die moontlike antwoorde van die respondente beperk tot bepaalde woordkeuse of formulering. In die metodologieafdeling van hierdie artikel sal meer oor die laaste aspek uitgebrei word.

Die doel van hierdie artikel is om die twee gestelde leemtes vir Afrikaans te vul, naamlik om eerstens te bepaal watter moontlike onverpersoonlikingstrategieë deur sprekers aangewend kan word, en tweedens te sien of daar bepaalde voorkeure vir sprekers bestaan oor watter strategieë om te gebruik in verskillende en onderskeibare onpersoonlike kontekste. Die hoop

$4 \quad$ In die volgende afdeling van die artikel sal aangetoon word dat vir die twee onpersoonlike gebruike, naamlik die universele en eksistensiële onpersoonlike gebruike, ook meerdere kontekste onderskei kan word. Daar kan naamlik vier universele onpersoonlike kontekste onderskei word, en agt eksistensiële onpersoonlike kontekste (vergelyk Van Olmen \& Breed, 2019). 
is dat die ondersoek na die Afrikaanse onpersoonlike konstruksies, ook bruikbaar kan wees vir ondersoeke na die onpersoonlike konstruksies in ánder tale.

Hierdie artikel bestaan voorts uit vier dele. In die volgende afdeling, Afdeling 2, word 'n kort beskrywing gegee van die verskillende onpersoonlike kontekste wat op grond van bepaalde kriteria onderskei kan word. Afdeling 3 betrek die metode van ondersoek wat in hierdie projek aangewend word. Hier word kortliks aangetoon watter beperkinge vorige ondersoeke na onpersoonlike konstruksies in Afrikaans (en ook ander Wes-Germaanse tale) gehad het. Die afdeling sit ook kortom die aanpak van hiérdie studie uiteen. Die vierde afdeling van die artikel bespreek die resultate van die ondersoek, en in die vyfde afdeling word 'n samevatting gemaak rakende die verskillende moontlike onverpersoonlikingstrategieë wat Afrikaanse sprekers kan gebruik, asook watter strategieë voorkeur geniet bo ander in die onderskeie onpersoonlike kontekste.

\section{Twaalf onderskeibare onpersoonlike kontekste en hul bepalende kriteria}

In Van Olmen en Breed (2018b) word - gebaseer op Siewierska en Papastathi (2011) en Gast en van der Auwera (2012) - twaalf onpersoonlike kontekste onderskei. Die kontekste kan van mekaar onderskei word op grond van sewe kriteria vir onverpersoonliking, naamlik i) kwantifisering, ii) perspektief, iii) waarheidsgetrouheid, iv) modaliteit, v) (on)bekendheid, vi) getal en vii) spraakhandeling. Die verskillende onpersoonlike kontekste, sowel as 'n Afrikaanse voorbeeld van elkeen, word in die tabel hier onder aangebied, gevolg deur 'n kort beskrywing van die sewe onpersoonlike kriteria of maatstawwe.

TABEL 1: Twaalf onpersoonlike kontekste

\begin{tabular}{|c|c|c|}
\hline & Onpersoonlike konteks & Afrikaanse voorbeeld \\
\hline 1 & UNI-INT-NVER-NMOD & $9 \quad$ Maar wat gebeur as mens afgedank word? \\
\hline 2 & UNI-INT-NVER-MOD & 10 Mens mag nie ondankbaar wees nie. \\
\hline 3 & UNI-INT-VER & 11 Jy leef net een keer. \\
\hline 4 & UNI-EXT & 12 In Suidwes eet hulle nie pap en vleis nie. \\
\hline 5 & EXI-COR & $\begin{array}{l}13 \text { Gebruikers van die tonnel moet bedag wees op verskeie } \\
\text { spoedkameras wat in die tonnel geïnstalleer is. }\end{array}$ \\
\hline 6 & EXI-VAG-PL & $\begin{array}{l}14 \text { Jou hond is op 'n paar plekke in die dorp gesien. (eie } \\
\text { voorbeeld) }\end{array}$ \\
\hline 7 & EXI-VAG-NN & 15 Iemand het sy klere gesteel. \\
\hline 8 & EXI-INF-PL & $\begin{array}{l}16 \text { As ons na die argeologiese bewyse kyk, sien ons hulle } \\
\text { het 'n nedersetting hier gevestig. (eie voorbeeld) }\end{array}$ \\
\hline 9 & EXI-INF-NN & $\begin{array}{l}17 \text { Tinus botstil staan en wys na gebreekte takke en gras- } \\
\text { polle wat vertrap is. Iemand het hier geloop. (aangepas) }\end{array}$ \\
\hline 10 & EXI-SPE-PL & $\begin{array}{l}18 \text { Hulle klop gelyktydig aan die voordeur en die agterdeur. } \\
\text { (eie voorbeeld) }\end{array}$ \\
\hline 11 & EXI-SPE-NN & 19 Ek is bietjie haastig. Iemand wag vir my langs die pad. \\
\hline 12 & SAV & $\begin{array}{l}20 \text { Hulle sê daar is bewyse dat lyfstraf' 'n geweldskultuur } \\
\text { vestig. }\end{array}$ \\
\hline
\end{tabular}


Die eerste kriterium, naamlik kwantifisering (quantification), dui aan of die onderwerp van die sin 'n universele kwantifisering (UNI) het. Verder is dit ook van toepassing op almal wat relevant is vir die konteks of wat in die spesifieke konteks ingesluit is (vergelyk voorbeelde 9 tot 12 hier bo) of dat dit 'n eksistensiële kwantifisering het (EXI) en aanvaar dat daar 'n spesifieke, maar nie-geïdentifiseerde (groep) individu(e) is waarop die toedrag van sake van toepassing is, soos in voorbeelde 13 tot 20.

Perspektief (perspective), as die tweede maatstaf, het betrekking op die spreker en/of die geadresseerde. Daar word gesê dat 'n onpersoonlike konteks as 'n konteks met 'n interne perspektief (INT) gereken word, wanneer die spreker hom- of haarself, of die hoorder by die konteks inreken (vergelyk ook Gast \& van der Auwera, 2013:139). Sinne 9 tot 11 dien as voorbeelde van onpersoonlike kontekste met 'n interne perspektief. Daarteenoor is sin 12 'n voorbeeld van 'n onpersoonlike konteks met 'n eksterne perspektief (EXT), aangesien die spreker en geadresseerde uitgesluit is by die perspektief.

Die derde maatstaf, waarheidsgetrouheid (veridicality), het te make met die waarheid van die toedrag van sake. 'n Konteks is waarheidsgetrou, oftewel veridies (VER), as die stand of toedrag van sake deur die spreker aangebied word as die waarheid of as geldend, soos in 11. 'n Konteks is niewaarheidsgetrou, oftewel nieveridies (NVER) as daar nie aangeneem kan word dat die stand of toedrag van sake waar of geldend is nie, en met ander woorde slegs hipoteties is, soos in 9 en 10.

Modaliteit (modality), die vierde maatstaf, het te make met die modale of niemodale vorm van 'n uiting. 'n Konteks is modaal (MOD) as die niewaarheidsgetrouheid daarvan deur middel van 'n modale vorm uitgedruk word, soos die werkwoord moet in 10. 'n Konteks is niemodaal (NMOD) wanneer die niewaarheidsgetrouheid daarvan op 'n ander manier oorgedra word as 'n modale uitdrukking, soos in die voorwaardesin in voorbeeld 9.

(On)bekendheid ((un)knownness), as die vyfde maatstaf, het betrekking op die hoeveelheid inligting rakende die (geïmpliseerde) subjek wat aan die spreker bekend is. Vier soorte (on)bekendhede kan onderskei word, naamlik i) deels bekend (partly known), ii) vaag (vague), iii) afgelei (inferred) en iv) spesifiek (specific). 'n Konteks is deels bekend as dit min of meer duidelik is uit die toedrag van sake wie die persoon of persone is wat daarvoor verantwoordelik is, alhoewel hulle nie eksplisiet genoem word nie (vergelyk voorbeeld 13). In sulke kontekste word die term "korporatief" (COR) dikwels gebruik. 'n Gebruik is vaag (VAG) wanneer die spreker weet van die spesifieke gebeurtenis wat beskryf word, maar nie die spesifieke persoon of persone wat daarvoor verantwoordelik is, kan identifiseer op grond van die beskikbare bewyse nie, soos in 14 en 15. 'n Gebruik word afgelei (INF) wanneer die werklike gebeurtenis nie bekend is nie, maar afgelei word van enkele tekens of bewyse in die situasie en die bestaan van die persoon of persone wat dit veroorsaak het, word ook aanvaar, soos in sinne 16 en 17. Laastens is 'n gebruik spesifiek (SPE) wanneer die spreker op dieselfde tyd en plek is as die persoon of persone wat die geleentheid daar en dan voltrek, en daarom 'n sterk vermoede kan hê oor wie die persoon of persone is, maar hulle steeds nie identifiseer nie, soos in sinne 18 en 19.

Die sesde maatstaf, getal (number), dui die aantal mense aan wat by die (geïmpliseerde) subjek ingesluit is. ' $\mathrm{n}$ Gebruik is meervoudig (plural) (PL) wanneer die onderwerp net meer as een persoon kan wees, soos in sinne 14, 16 en 18. 'n Gebruik is getalneutraal (number neutral) (NN) wanneer die getal van die (geïmpliseerde) subjek nie bekend is nie en dit kan een persoon of meer as een persoon wees, soos in sinne 15, 17 en 19.

Die sewende en laaste kriterium het te make met 'n gebruik waarin 'n spraakhandelingwerkwoord (speech act verb) (SAV) soos "sê" en "beweer" voorkom en die (geïmpliseerde) 
subjek maklik deur "mense" vervang kan word. Dit het 'n bewysfunksie deurdat die spreker 'n uiting toeskryf aan 'n onbepaalde stel individue. Sin 20 is 'n voorbeeld.

\section{Metode van ondersoek}

Soos vroeër aangetoon, kan bepaalde beperkinge uitgelig word in die wyse waarop vorige metodes onpersoonlike konstruksies probeer bestudeer het. Naas die feit dat die genoemde metodes nie geleentheid bied vir navorsers om moontlik núwe of onbekende onverpersoonlikingstrategieë te identifiseer nie, en ook naas die feit dat korpora nie altyd genoegsame voorbeelde van al twaalf onpersoonlike kontekste bevat nie, is ook die vraelyste wat tot op hede gebruik is, te beperkend om werklik tot sinvolle insigte te lei rondom nuwe of voorkeurstrategieë van onverpersoonliking.

Die vraelysgebaseerde ondersoek van Van Olmen en Breed (2018a; 2018b) kan hier as voorbeeld dien om die beperkinge rondom die gebruik van vraelyste om onverpersoonlikingstrategieë te ondersoek, te illustreer. In hul studie is 'n sogenaamde "dubbelvraelysgebaseerdebenadering" gevolg. Met ander woorde, twee verskillende vraelyste, naamlik 'n aanvaarbaarheidsoordeeltaak (AOT) en 'n voltooitaak (VT), is gebruik om data in te samel rakende onverpersoonlikingstrategieë in drie Wes-Germaanse tale - Afrikaans, Nederlands en Engels.

Albei vraelyste is ontwerp om die gebruik van verskillende persoonlike voornaamwoorde in twaalf onpersoonlike kontekste deur sprekers van elk van die drie tale te toets. Elke konteks is geskommel aan die respondent aangebied as twee verskillende scenario's. Die vraelys het dus uit 24 vrae bestaan. Die respondente moes dan, afhangende van die vraelys wat hul beantwoord, 'n spesifieke taak uitvoer om die aanvaarbaarheid van 'n spesifieke onpersoonlike voornaamwoord te toets of om hul eie voorkeuronverpersoonlikingstrategie te verskaf (maar beperk tot voornaamwoordelike of naamwoordelike strategie). Figuur 1 is 'n uittreksel uit die Afrikaanse AOT.

Soos hier bo gesien kan word, is verskillende scenario's wat die onderskeibare onpersoonlike kontekste uitbeeld, aan die respondent voorgehou. Die respondent is daarna gevra om op 'n skaal van 1 tot 5 aan te dui ( 1 is heeltemal onaanvaarbaar en 5 is heeltemal aanvaarbaar) tot watter mate hy of sy die gebruik van elk van die verskillende Afrikaanse voornaamwoorde in die gegewe konteks aanvaarbaar vind. Figuur 2 is 'n uittreksel uit die Afrikaanse VT.

Die VT is gebaseer op dieselfde twaalf kontekste (wat twee keer in verskillende scenario's aangebied is en dus net soos die AOT uit 24 vrae bestaan het). Die verskil tussen die AOT en die VT was egter dat die sintaktiese posisie waarin die verskillende persoonlike voornaamwoorde in die AOT aan die respondente voorgehou is, in die VT oopgelaat is. Die respondent moes sy of haar eie moontlike antwoord verskaf. Met ander woorde, die voorbeelde hier bo dui aan hoe die VT gebruik is om te bepaal wat die voorkeurstrategie van elk van die respondente in die EXI-INF-NN-konteks sou wees (vergelyk weer Tabel 1). Dit sou dus vir die respondent moontlik wees om 'n persoonlike voornaamwoord soos $j y$ en hulle in te vul, maar ook 'n ander moontlike strategie, byvoorbeeld 'n onbepaalde voornaamwoord soos iemand. Die VT was egter beperk tot onpersoonlike strategieë wat as subjek funksioneer, en dit was nie vir die respondent moontlik om die antwoord te herskryf of te herformuleer nie. Dit was byvoorbeeld nie moontlik vir die respondent om 'n passiewe antwoord te gee in plaas daarvan om 'n voornaamwoordelike of naamwoordelike subjek te gebruik nie.

'n Vraelysbenadering is egter steeds voordelig vir taalkundige studie, aangesien dit o.a. ruimte laat om - soos inderdaad die geval is met sommige onpersoonlike kontekste - 
Jy en jou vriendin vat jou kinders een oggend parkie toe om te gaan speel. Daar lê 'n klomp leë bierblikkies in die parkie rond en jy sê vir jou vriendin:

$\begin{array}{lllll}1 & 2 & 3 & 4 & 5\end{array}$

"Mens het hier bymekaargekom vir 'n partytjie."

"'n Mens het hier bymekaargekom vir 'n partytjie."

"Man het hier bymekaargekom vir 'n partytjie."

"'n Man het hier bymekaargekom vir 'n partytjie."

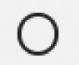

0
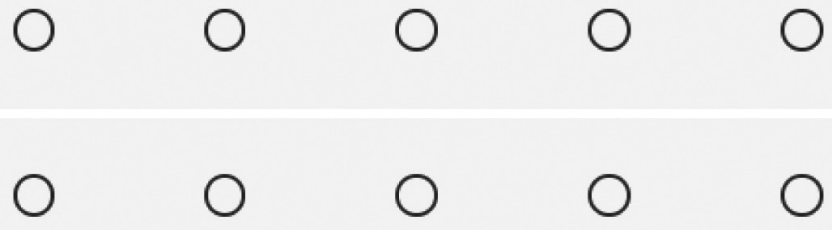

"Hin 'n partytie."

"Hulle het hier bymekaargekom vir 'n partytjie."

"Jy het hier bymekaargekom vir 'n partytjie."
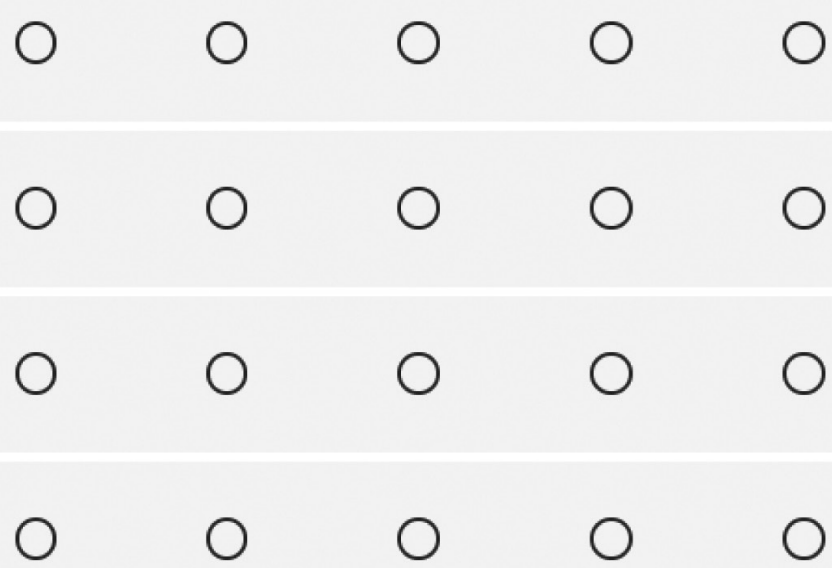

Figuur 1: $\quad$ Uittreksel uit die Afrikaanse aanvaarbaarheidsoordeeltaak van Van Olmen \& Breed (2018a; 2018b)

8. Jy en jou vriendin vat jou kinders een oggend parkie toe om te gaan speel. Daar lê 'n klomp leë bierblikkies in die parkie rond en jy sê vir jou vriendin: " het hier bymekaargekom vir 'n partytjie."

Jou antwoord

Figuur 2: $\quad$ Uittreksel uit die Afrikaanse voltooitaak van Van Olmen \& Breed (2018a, 2018b) 
taalstrukture te ondersoek wat nie frekwent in taalgebruik, en derhalwe in korpora, voorkom nie. Indien dus van 'n vraelys gebruik gemaak word om eerstens die moontlike en tweedens die voorkeurstrategieë van onverpersoonliking in Afrikaans en ander tale te bestudeer, moet 'n vraelys gebruik word, wat i) nie die moontlike talige antwoorde van respondente beperk nie, ii) in staat is om enige moontlike onverpersoonlikingstrategie te akkommodeer, iii) geen bevooroordeelde, leidende of beperkende taalkundige leidrade of instruksies bevat nie, en iv) rekening hou met al die kriteria waarvolgens die twaalf onpersoonlike gebruike van mekaar onderskei word.

Daar is dus besluit om vir hierdie projek 'n soortgelyke vraelys as dié van Van Olmen en Breed (2018a, 2018b) te ontwikkel. 'n Ander benadering word egter gevolg: In plaas daarvan om die onpersoonlike kontekste in die vraelys aan te bied in die vorm van geformuleerde beskrywings van scenario's, word die kontekste eerder as visuele voorstellings aangebied. Respondente sou dus die kontekste kon evalueer en antwoorde kon bedink sonder om 'n spesifieke formulering hoef te gebruik.

Figuur 3 is ' $n$ uittreksel uit die visuele vraelys wat vir hierdie projek ontwerp ${ }^{5}$ is. Die konteks wat aangebied word, is ook - net soos die uittreksels uit die AOT en VT - van 'n EXI-INF-NN-konteks. Die doel van hierdie visuele vraelys was uitsluitlik om i) 'n verskeidenheid van moontlike onverpersoonlikingstrategieë te identifiseer, en ii) te sien of sprekers bepaalde voorkeurstrategieë aanwend in sekere onpersoonlike kontekste.

Die visuele vraelys het bestaan uit 12 vrae. Elke vraag het een van die twaalf onderskeibare onpersoonlike kontekste deur 'n visuele illustrasie voorgestel. Die voorstelling van die SAVkonteks het egter te min bruikbare antwoorde opgelewer, en word derhalwe nie by die resultate ingesluit nie. Ter wille daarvan om soveel as moontlike bruikbare antwoorde te bekom, is die illustrasies ook met kontekstuele leidrade toegelig. Die kontekstuele leidrade was meestal slegs 'n versoek dat die respondent 'n spesifieke werkwoord, en soms ook 'n bykomende bywoord of naamwoord moet gebruik om die visuele voorstelling te beskryf. 'n Kopie van die elektroniese vraelys wat aan respondente voorgehou is, kan aanlyn ${ }^{6}$ beskou word. Figuur 3 hier onder bied voorbeelde van geskikte antwoorde wat deur respondente aangebied is wat die visuele vraelys beantwoord het. Elkeen van die antwoorde beskryf 'n ander onpersoonlike konteks.

$5 \quad$ Hierdie projek het die vorm aangeneem van 'n samewerkende, interdissiplinêre projek wat gegrond is in die taalkundeteorie oor onverpersoonliking en die visuele kommunikasieteorie op woordlose visuele narratiewe (wordless visual narratives) (vergelyk Nodelman, 1990; Horwat, 2018:176; Arif \& Hashim, 2008:121). Die interdissiplinêre groep van agtien medewerkers bestaan uit twee taalkundiges, een dosent in grafiese ontwerp en vyftien studente in die grafiese ontwerp. Die ontwikkeling van die vraelys is uitgevoer as 'n praktykgebaseerde navorsingsprojek, met die onderrig- en leerdoel om studente in grafiese ontwerp op te lei om die beperkinge en interaksies van 'n kliëntopdrag te navigeer. Die twee taalkundiges het die rol van die kliënt aangeneem en die kommissieopdrag het gestel dat die vyftien studente, onder leiding van hul dosent, verantwoordelik was daarvoor om die visuele voorstellings van die onpersoonlike gebruike wat as "visuele vrae of aanwysings" gebruik sal word, te illustreer vir die vraelys. In Breed et al. (2021) word hierdie ontwerp- en evalueringsproses omvattend beskryf, en dit word daarom nie in hierdie artikel verder bespreek nie.

6 Die vraelys kan by die volgende skakel beskou word: https://forms.gle/WgNaFXWhoojKejKo9

Tydskrif vir Geesteswetenskappe, Jaargang 61 No. 4-1: Desember 2021

doi.10.17159/2224-7912/2021/v61n4-1a7 

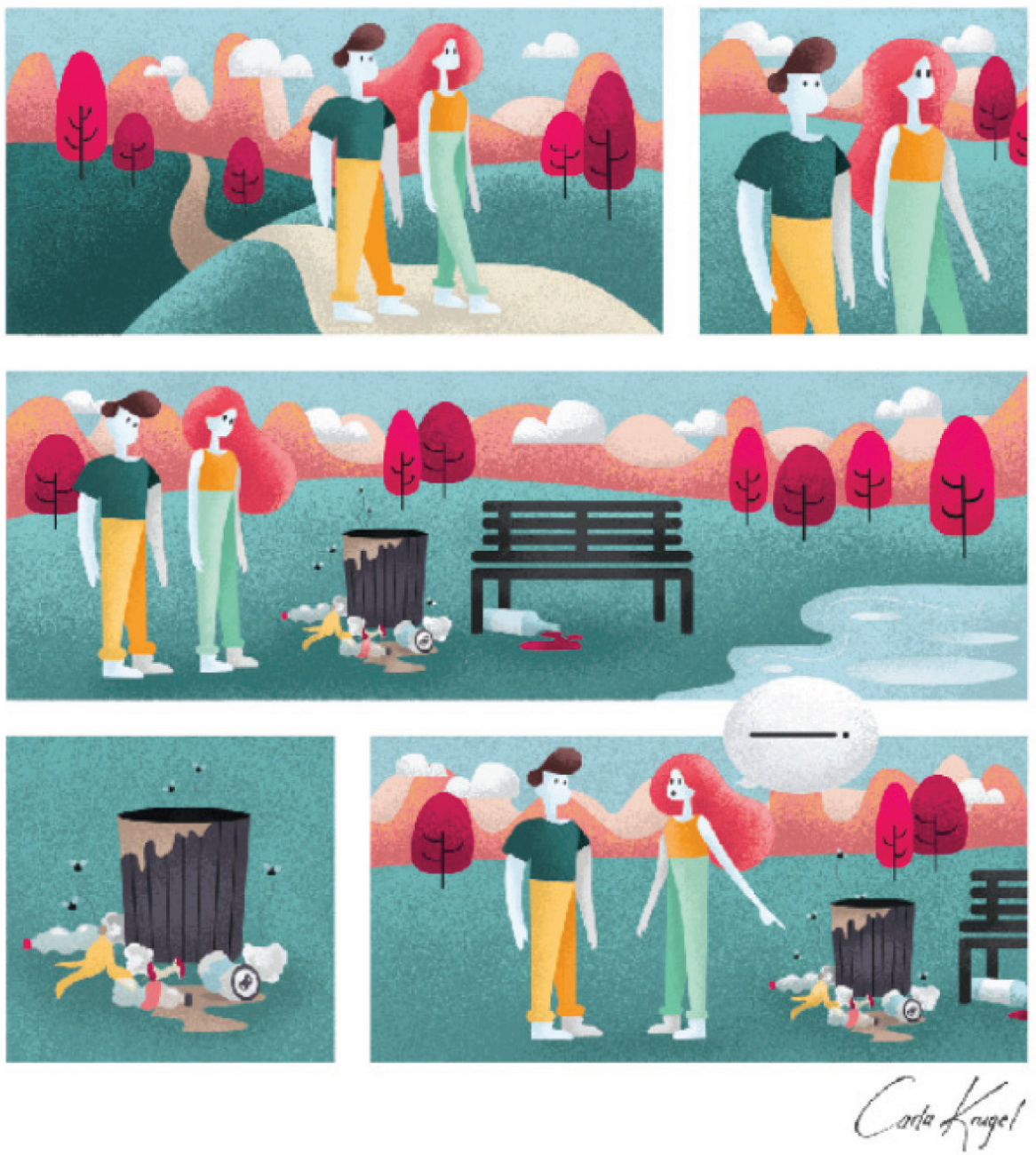

[0.098] Formuleer asseblief die stelling wat in die spraakborrel gemaak word. Gebruik asseblief die werkwoord "drink"/"gedrink" en die woorde "hier" en "gister" in jou antwoord. *

Jou antwoord

Figuur 3: $\quad$ Uittreksel uit die visuele vraelys oor onverpersoonlikingstrategieë 
TABEL 2: Bruikbare antwoorde vanuit die visuele vraelys vir elke onpersoonlike konteks

\begin{tabular}{|c|l|ll|}
\hline & Onpersoonlike konteks & Geskikte voorbeelde vanuit antwoorde van visuele vraelys \\
\hline 1 & UNI-INT-NVER-NMOD & 21 & Wat gebeur as mens dié rooi knoppie druk? \\
\hline 2 & UNI-INT-NVER-MOD & 22 & $\begin{array}{l}\text { 'n Mens moet altyd jou sitplekgordel vasmaak as jy } \\
\text { motor bestuur. }\end{array}$ \\
\hline 3 & UNI-INT-VER & 23 & Almal kry koud in die winter. \\
\hline 4 & UNI-EXT & 24 & Mense in China eet baie rys. \\
\hline 5 & EXI-COR & 25 & Hulle werk alweer aan die pad. \\
\hline 6 & EXI-VAG-PL & 26 & $\begin{array}{l}\text { Hulle het terreuraanvalle op 'n paar plekke in die stad } \\
\text { uitgevoer. }\end{array}$ \\
\hline 7 & EXI-VAG-NN & 27 & Iemand het al die appels gepluk terwyl jy geslaap het! \\
\hline 8 & EXI-INF-PL & 28 & Lyk of iemand gister hier sokker gespeel het. \\
\hline 9 & EXI-INF-NN & 29 & $\begin{array}{l}\text { Hulle het natuurlik gister hier gedrink en nie skoon } \\
\text { gemaak nie. }\end{array}$ \\
\hline 10 & EXI-SPE-PL & 30 & Iemand het sowaar al die koek opgeëet! \\
\hline 11 & EXI-SPE-NN & 31 & O gats! Iemand het my gehoor! \\
\hline
\end{tabular}

Die vraelys is op sosiale media versprei en in totaal het 451 Afrikaanssprekende respondente die aanlyn vraelys voltooi en ingedien. Deelname was anoniem en vrywillig, maar deelnemers kon aandui of hul wil deelneem aan 'n lukrake en gelukkige e-postrekking waardeur vier deelnemers 'n geskenkbewys van 'n aanlyn winkel ontvang het. Die deelnemers se kontakbesonderhede is nie in die datastel opgeneem nie.

Persone vanuit verskillende ouderdomsgroepe het die vraelys voltooi, asook persone van verskillende geslagte. Alle respondente was eerstetaalsprekers van Afrikaans, of meertalige sprekers wat aangedui het dat hul Afrikaans so goed as eerstetaalsprekers handhaaf. Hoewel nie álle antwoorde wat respondente aangebied het, bruikbaar was om die onverpersoonlikingstrategieë in Afrikaans te ondersoek nie, was alle vraelyste bruikbaar en almal is in die datastel opgeneem. Soos reeds genoem, is die vraag oor die SAV-konteks nié by die studie ingesluit nie. Slegs 11 vrae se antwoorde is derhalwe in die studie betrek.

\section{Die resultate}

Soos genoem, het 451 respondente in totaal aan die vraelys deelgeneem. 'n Paar opmerkings is hier ter sake. Eerstens, hoewel die meeste respondente alle vrae in die vraelyste beantwoord het, is daar enkele vraelyste waarin nie alle vrae deur die respondent beantwoord is nie. Tweedens het 'n respondent soms 'n vraag só beantwoord, dat die antwoord nie bruikbaar was vir die betrokke onpersoonlike konteks wat getoets word nie, maar eerder 'n ander onpersoonlike konteks. Daar was byvoorbeeld sommige respondente wat die UNI-EXT (met Mense in China eet baie rys as geskikte voorbeeld) beantwoord het as 'n UNI-INT-VER-konteks (byvoorbeeld In China eet mens rys). In 'n INT-konteks, beskou die spreker hom- of haarself as 'n persoon wat self ook rys sal eet wanneer hy of sy China besoek, terwyl'n EXT-konteks die spreker by die situasie uitsluit. As vrae dus anders beantwoord is as waarvoor die betrokke visuele vraag ontwerp is, is die antwoorde nie by die resultate opgeneem nie. Derdens het sommige respondente meer as een onverpersoonlikingstrategie in hul antwoorde aangewend. Elke onderskeibare strategie is apart gemerk. Vir 'n UNI-INT-NVER-MOD-antwoord soos 
"Maak seker die sitplekgordel is stewig vasgemaak" sal byvoorbeeld aangedui word of die respondent ' $n$ bevelsvorm as onverpersoonlikingstrategie gebruik het, asook 'n agenslose passief. Laastens was sommige antwoorde meerduidig in terme van 'n persoonlike of onpersoonlike interpretasie. Dit was byvoorbeeld nie duidelik in 'n antwoord soos Ek moet my sitplekgordel vasmaak, of die respondent bedoel het om na hom- of haarself te verwys, of na die totale mensdom - waarbinne hy of sy hom- of haarself inreken (vergelyk ook Zobel, 2015 oor die Duitse ich) nie. Alle gevalle wat op hierdie wyse meerduidig ${ }^{7}$ was, is by die resultate ingereken. Hoewel daar in totaal 451 vraelyste ontvang is, en hoewel elke vraelys een vraag per onpersoonlike konteks bevat het, is daar dus nie vir elke konteks noodwendig presies 451 antwoorde verskaf nie. Tabel 3 bied 'n opsomming van die aantal bruikbare antwoorde wat deur die respondente aangebied is.

TABEL 3: Opsomming van bruikbare antwoorde

\begin{tabular}{|l|c|c|c|}
\hline Konteks & $\begin{array}{c}\text { TOTAAL } \\
\text { BRUIKBAAR }\end{array}$ & $\begin{array}{c}\text { TOTAAL } \\
\text { ONBRUIKBAAR }\end{array}$ & TOTAAL \\
\hline UNI-INT-NVER-NMOD & 382 & 68 & 450 \\
UNI-INT-NVER-MOD & 360 & 92 & 452 \\
\hline UNI-INT-VER & 119 & 335 & 454 \\
\hline UNI-EXT & 288 & 165 & 453 \\
\hline EXI-COR & 362 & 77 & 439 \\
\hline EXI-VAG-PL & 424 & 25 & 449 \\
\hline EXI-VAG-NN & 343 & 107 & 450 \\
\hline EXI-INF-PL & 221 & 227 & 448 \\
\hline EXI-INF-NN & 371 & 78 & 449 \\
\hline EXI-SPE-PL & 245 & 206 & 451 \\
\hline EXI-SPE-NN & 187 & 224 & 411 \\
\hline TOTAAL & 3302 & 1604 & 4906 \\
\hline
\end{tabular}

In totaal is 4906 antwoorde ontvang ('n gemiddeld van 446 antwoorde per konteks). Ongeveer 'n derde van die antwoorde (1 604 antwoorde) was egter nie bruikbaar vir hierdie studie nie, aangesien dit óf nie voorbeelde was van onverpersoonlikingstrategieë nie, óf die respondent het nie die relevante onpersoonlike konteks met sy of haar antwoord beskryf nie. Hierdie aantal onbruikbare antwoorde is nie heeltemal onverwags nie, gegewe die aard van die vraelys (wat baie oop is) en die aard van die semantiese domein wat ondersoek word (wat baie moeilik is om te visualiseer en uit te lok). Nietemin is in totaal meer as 3300 antwoorde aangebied wat wél as geskikte en bruikbare voorbeelde van onverpersoonlikingstrategieë gereken kan word. Vir alle kontekste (met die uitsondering van die SAV-konteks) is boonop genoeg antwoorde aangebied om 'n verskeidenheid van moontlike onverpersoonlikingstrategieë te

\footnotetext{
7 'n Toets vir 'n moontlike meerduidige antwoord, was of die meerduidige konstruksie sinvol deur 'n ander onpersoonlike strategie, byvoorbeeld 'n onbepaalde voornaamwoord vervang kan word. Dit was byvoorbeeld moontlik om die 1.SG-voornaamwoord, $e k$, te vervang met die onbepaalde voornaamwoord almal. Die interpretasie van die sin sou dan sonder twyfel onpersoonlik wees. Daar sou egter antwoorde kon wees wat vir ons as taalkundiges meerduidig was, maar wat die respondente nie as onpersoonlik bedoel het nie.
} 
identifiseer, asook om voorlopige gevolgtrekkings te kan maak oor voorkeurstrategieë wat sprekers binne spesifieke kontekste aanwend.

Uit Tabel 3 is dit ook duidelik dat vir sommige kontekste meer bruikbare antwoorde verskaf is as ander kontekste. Vir die EXI-VAG-PL-konteks is byvoorbeeld 424 bruikbare antwoorde aangebied, terwyl vir die UNI-INT-VER-konteks slegs 119 bruikbare antwoorde aangebied is. Ons is egter van mening dat daar vir alle kontekste 'n genoegsame hoeveelheid bruikbare antwoorde verskaf is om sinvolle afleidings te mak oor die moontlike en voorkeurstrategieë van onverpersoonliking in Afrikaans.

Die resultate word vanuit drie perspektiewe bespreek. Eerstens word die totale resultate as 'n geheelbeeld geïnterpreteer. Tweedens word elke onderskeibare onverpersoonlikingstrategie aangebied en bespreek en derdens kry die verskillende strategieë wat in elke afsonderlike onpersoonlike konteks gebruik is, aandag.

\subsection{Totale resultate van alle vraelyste se antwoorde}

Vanuit die literatuur wat vroeër genoem is, is veral vier onverpersoonlikingstrategieë bekend wat in Afrikaans (maar ook ander Wes-Germaanse tale) gebruik word, naamlik i) persoonlike voornaamwoorde wat op onpersoonlike wyse aangewend word, soos jy en hulle; ii) die naamwoordstukke ('n) mens en (die) mense; iii) onbepaalde voornaamwoorde soos iemand en almal; en iv) passiefkonstruksies.

Tabel 4 en Figuur 4 bied 'n opsomming van al die onverpersoonlikingstrategieë wat in al die antwoorde in al die vraelyste aangebied is deur Afrikaanse sprekers. Hier sien ons dat die genoemde vier strategieë inderdaad algemeen in Afrikaans aangewend word in onpersoonlike kontekste. Naas hierdie vier bekende strategieë, het respondente egter ook 'n aantal strategieë aangebied wat nog nie vantevore as onverpersoonlikingstrategieë in Afrikaans geïdentifiseer is nie. Hierdie strategieë sal in Afdeling 4.2 meer spesifieke aandag kry.

'n Aantal belangrike of opvallende afleidings kan gemaak word deur na die totale van die verskillende onverpersoonlikingstrategieë te kyk. Eerstens is dit duidelik dat die voornaamwoordelike strategie - maar meer spesifiek, die gebruik van persoonlike voornaamwoorde in onpersoonlike kontekste - die algemeenste wyse is waarop 'n Afrikaanse spreker aantoon dat 'n bepaalde konteks onpersoonlik is. Dié resultate bevestig die belangrikheid van persoonlike voornaamwoorde ${ }^{8}$ as onverpersoonlikingstrategie in taalgebruik wat deur ' $n$ aantal navorsers aangetoon is (vergelyk byvoorbeeld - om maar enkeles te noem - van der Auwera et al., 2012; Malamud, 2012; Deringer et al., 2015; en Rudolf, 2014). Feitlik al die persoonlike voornaamwoorde (met die uitsondering van 3.SG) is in die resultate van ons vraelyste aangewend as onverpersoonlikingstrategieë. Die hoë frekwensie van die 2.SG en 3.PL kan verklaar word deur die verduidelikings van Van Olmen \& Breed (2018a, 2018b), naamlik dat die gebruik van 2.SG 'n onverpersoonlikingstrategie is wat gereeld gebruik word in die UNI-INT-kontekste, terwyl die 3.PL die primêre onverpersoonlikingstrategie is wat gebruik word in alle EXIkontekste, sowel as UNI-EXT-kontekste. Die hoë frekwensie van 1.SG skryf ons toe aan die

In die literatuur oor onpersoonlike konstruksies, word meestal na persoonlike voornaamwoorde wat in onpersoonlike kontekste aangewend word, verwys as "menslike onpersoonlike voornaamwoorde" (human impersonal pronouns). Hierdie onpersoonlike voornaamwoorde kan gedefinieer word as die "pronominal expression of impersonalization, i.e. the process of filling an argument position of a predicate with a variable ranging over sets of human participants without establishing a referential link to any entity from the universe of discourse" (Gast \& van der Auwera, 2013:124).

Tydskrif vir Geesteswetenskappe, Jaargang 61 No. 4-1: Desember 2021 doi.10.17159/2224-7912/2021/v61n4-1a7 
TABEL 4: Opsomming van alle bruikbare antwoorde uit die visuele vraelys oor onverpersoonlikingstrategieë in Afrikaans

\begin{tabular}{|c|c|c|c|c|c|}
\hline \multicolumn{2}{|c|}{ Onverpersoonlikingstrategie } & \multirow{2}{*}{$\begin{array}{l}\begin{array}{l}\text { Sub- } \\
\text { totaal }\end{array} \\
306\end{array}$} & \multirow{2}{*}{ Totaal } & \multicolumn{2}{|c|}{ Bruikbare voorbeeld uit vraelys } \\
\hline \multirow{6}{*}{$\begin{array}{l}\text { Persoonlike } \\
\text { voornaamwoorde } \\
\text { (PN.PERS) }\end{array}$} & PN.PERS.1.SG & & & 32 & $\begin{array}{l}\text { Ek maak altyd my sitplekgordel } \\
\text { vas. (UNI-INT-NVER-MOD) }\end{array}$ \\
\hline & PN.PERS.2.SG & 127 & \multirow[b]{5}{*}{1006} & 33 & $\begin{array}{l}\text { Wat gebeur as jy die knoppie } \\
\text { druk? (UNI-INT-NVER-NMOD) }\end{array}$ \\
\hline & PN.PERS.1.PL & 16 & & 34 & $\begin{array}{l}\text { In die winter kry ons koud. (UNI- } \\
\text { INT-VER) }\end{array}$ \\
\hline & PN.PERS.2.PL & 3 & & & $\begin{array}{l}\text { Maak seker dat julle } \\
\text { sitplekgordels vasgemaak is } \\
\text { wanneer julle ry. (UNI-INT- } \\
\text { NVER-MOD) }\end{array}$ \\
\hline & PN.PERS.3.PL & 554 & & 36 & $\begin{array}{l}\text { Hulle werk alweer aan die pad. } \\
\text { (EXI-COR) }\end{array}$ \\
\hline & & & & 37 & \\
\hline \multirow{4}{*}{$\begin{array}{l}\text { Onbepaalde } \\
\text { voornaamwoorde } \\
\text { (PN.INDF) }\end{array}$} & iemand & 473 & \multirow[b]{4}{*}{515} & 38 & $\begin{array}{l}\text { Ek dink iemand het my gehoor. } \\
(E X I-V A G-N N)\end{array}$ \\
\hline & almal & 40 & & & $\begin{array}{l}\text { Almal moet hulle sitplekgordel } \\
\text { vasmaak. (UNI-INT-NVER-MOD) }\end{array}$ \\
\hline & elkeen & 2 & & & $\begin{array}{l}\text { Elkeen moet hul sitplekgordel } \\
\text { vasmaak. (UNI-INT-NVER-MOD) }\end{array}$ \\
\hline & & & & 41 & \\
\hline \multirow{3}{*}{$\begin{array}{l}\text { Gegrammatikaliseerde } \\
\text { naamwoorde of } \\
\text { naamwoordstukke } \\
\text { (NP) }\end{array}$} & ('n) mens & 123 & \multirow[b]{3}{*}{312} & & $\begin{array}{l}\text { In die winter kry mens koud. } \\
\text { (UNI-INT-VER) }\end{array}$ \\
\hline & (die) mense & 189 & & & $\begin{array}{l}\text { Mense in China eet baie rys. } \\
\text { (UNI-EXT) }\end{array}$ \\
\hline & & & & 44 & \\
\hline $\begin{array}{l}\text { Passiefkonstruksies } \\
\text { (PASS) }\end{array}$ & & & 955 & & $\begin{array}{l}\text { Terwyl jy geslaap het is al die } \\
\text { appels gepluk. (EXI-VAG-NN) }\end{array}$ \\
\hline $\begin{array}{l}\text { Ander moontlike } \\
\text { onverpersoonliking- } \\
\text { strategieë }\end{array}$ & & & 510 & & \\
\hline \multicolumn{3}{|l|}{ TOTAAL } & 3298 & & \\
\hline
\end{tabular}

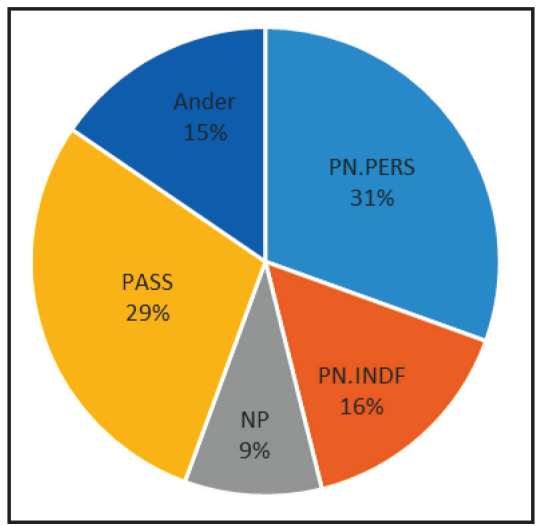

Figuur 4: $\quad$ Opsomming van alle bruikbare antwoorde uit die visuele vraelys oor onverpersoonlikingstrategieë in Afrikaans 
meerduidige aard van die meeste van die antwoorde in die drie UNI-INT-kontekste, waar dit telkens nie heeltemal duidelik is of die respondent bedoel om op referensiële wyse na hom- of haarself te verwys (byvoorbeeld sin 32), of eerder op 'n niereferensiële wyse bedoel dat hy of sy deel vorm van die universele groep persone wat in die konteks ter sprake is (byvoorbeeld 34) nie.

'n Tweede, taamlik verrassende afleiding wat uit die resultate gemaak kan word, is dat die gebruik van 'n passiefkonstruksie byna 'n ewe algemene onverpersoonlikingstrategie is as die voornaamwoordelike strategie. Byna $30 \%$ van alle onverpersoonlikingstrategieë wat Afrikaanse sprekers gebruik het, was passiefkonstruksies. Hoewel die literatuur oor onpersoonlike konstruksies die passief aandui as 'n moontlike strategie van onverpersoonliking, is daar onsens insiens nie in enige literatuur aangedui hoe belangrik die funksie wat die passiefkonstruksie as onverpersoonlikingstrategie verrig, werklik vir Afrikaanse sprekers is nie.

'n Derde interessante bevinding is die hoë frekwensie van die persoonlike voornaamwoord $j y$ as onverpersoonlikingstrategie om die visuele onpersoonlike kontekste te beskryf. Van Olmen et al. (2019) dui aan dat beide jy en ('n) mens as onverpersoonlikingstrategieë in die vier UNI-kontekste aangewend kan word. Dié twee strategieë is sinonimies en is derhalwe uitwisselbaar. Die respondente van die Afrikaanse voltooitaak (vergelyk weer Figuur 2), het albei strategieë gebruik om die UNI-kontekste in hierdie vraelys te beantwoord. Van die twee strategieë, is die gebruik van ('n) mens egter by verre meer gereeld deur respondente in die VT ingevul. In totaal is ('n) mens 318 keer deur respondente as onverpersoonlikingstrategie by UNI-kontekste ingevul, terwyl $j y$ slegs 58 keer ingevul is. Ons het dus verwag dat respondente die UNI-kontekste in die visuele vraelys ook sou formuleer deur hoofsaaklik gebruik te maak van ('n) mens. In hiérdie vraelys is die twee strategieë egter byna ewe gereeld gebruik - daar is in 127 antwoorde van $j y^{9}$ gebruik gemaak, en in 123 antwoorde van ('n) mens. Die saak sal ook verder bespreek word in Afdeling 4.2.

Aangesien daar heelwat in die literatuur oor Afrikaanse onpersoonlike konstruksies (vergelyk Breed \& Van Olmen, 2017; Van Olmen \& Breed, 2018a; Van Olmen \& Breed, 2018b; Van Olmen et al., 2019; Breed et al., 2021; Groenen, 2021) oor dié onverpersoonlikingstrategieë bekend is, gaan daar nie verder in die artikel aandag gegee word aan die vier reeds bekende strategieë nie.

\subsection{Die onderskeibare onverpersoonlikingstrategië}

In Tabel 4 is 'n opsomming gegee van die verskillende onverpersoonlikingstrategieë wat deur respondente gebruik is om die visuele onpersoonlike kontekste te illustreer. Daar is ook aangedui dat in 510 antwoorde ánder onverpersoonlikingstrategieë aangewend is as die vier reeds bekende strategieë. Hierdie antwoorde is verder gegroepeer en gekategoriseer, en word in Tabel 5 opgesom.

$9 \quad$ Weereens was dit nie altyd noodwendig duidelik of die respondente $j y$ as persoonlik of onpersoonlik bedoel het nie. Maar aangesien alle 2.SG-antwoorde 'n meerduidige interpretasie kan hê, is dit wel hier gereken as 'n onverpersoonlikingstrategie. 
TABEL 5: Opsomming van ander onverpersoonlikingstrategieë

\begin{tabular}{|c|c|c|}
\hline Beskrywing van strategie & Geskikte voorbeeld & TOTAAL \\
\hline Gespesifiseerde NP & $\begin{array}{l}46 \text { Kwajongens het sowaar al die appels gepluk } \\
\text { terwyl jy geslaap het. (EXI-VAG-NN) }\end{array}$ & 221 \\
\hline Imperatief & $\begin{array}{l}47 \text { Maak nie saak wie jy is nie, maak altyd jou } \\
\text { sitplekgordel vas! (UNI-INT-NVER-MOD) }\end{array}$ & 124 \\
\hline $\mathrm{NP}+\mathrm{PN} \cdot \mathrm{REL}$ & $\begin{array}{l}48 \text { Die mense wat gister hier sokker gespeel het, } \\
\text { het hul bal hier vergeet. (EXI-INF-PL) }\end{array}$ & 81 \\
\hline Infinitief & $\begin{array}{l}49 \text { Kyk hoe lyk die verkeer! Is dit nou 'n tyd om } \\
\text { aan die pad te werk? (EXI-COR) }\end{array}$ & 38 \\
\hline Nominalisering & $\begin{array}{l}50 \text { Vasmaak van 'n sitplekgordel is verpligtend. } \\
\text { (UNI-INT-NVER-MOD) }\end{array}$ & 12 \\
\hline $\begin{array}{l}\text { Die NP impliseer 'n betrokke } \\
\text { agens }\end{array}$ & $\begin{array}{l}51 \text { Daar was terreuraanvalle op 'n paar plekke in } \\
\text { die stad gewees. (EXI-VAG-PL) }\end{array}$ & 16 \\
\hline Subjunktiewe Q-WHs & $\begin{array}{l}52 \text { Watter vraat het al die koek opgeëet? } \\
\text { (EXI-SPE-PL) }\end{array}$ & 8 \\
\hline Vryekeuse-items (FKI) & $\begin{array}{l}53 \text { Enige iemand wat 'n motor wil bestuur, moet } \\
\text { hul vasmaak met 'n sitplekgordel. } \\
\text { (UNI-INT-NVER-NMOD) }\end{array}$ & 3 \\
\hline Kwantifiseerder + NP & $\begin{array}{l}54 \begin{array}{l}\text { Meeste mense kry koud in die winter. } \\
\text { (UNI-INT-VER) }\end{array} \\
\end{array}$ & 4 \\
\hline Ken agensskap aan die NP toe & $\begin{array}{ll}55 & \text { Wat doen die knoppie? } \\
\text { (UNI-INT-NVER-NMOD) }\end{array}$ & 2 \\
\hline Persoon of persone & $\begin{array}{l}56 \text { Daar het sekerlik meer as } 3 \text { persone hier } \\
\text { gedrink gister. (EXI-INF-NN) }\end{array}$ & 1 \\
\hline TOTAAL & & 510 \\
\hline
\end{tabular}

'n Eerste strategie wat sprekers gebruik het om nié die subjek referensieel te spesifiseer nie, is 'n strategie wat ons as "ander strategieë" geklassifiseer het. Hierdie strategie is egter nie werklik 'n onverpersoonlikingstrategie nie, maar eerder 'n strategie om 'n subjek as onbepaald uit te druk. Sprekers het in hierdie konteks veral gebruik gemaak van 'n gespesifiseerde naamwoord om niereferensieel na 'n persoon of groep persone te verwys. Die naamwoord is meestal 'n naamwoord wat relevant is tot die bepaalde konteks, en 'n naamwoord wat byvoorbeeld die aksie wat die subjek uitvoer, insluit. So is die naamwoord "terroriste" byvoorbeeld gebruik om te verwys na "mense wat terroristiese aanvalle uitvoer" of die naamwoord "motorbestuurders" gebruik om te verwys na "mense wat motors bestuur". Hoewel die naamwoorde dus verwys na 'n spesifieke persoon of persone binne 'n bepaalde konteks, is dit - net soos die naamwoordstuk die mense - 'n niereferensiële verwysing na 'n groep mense. Hierdie strategie word hoofsaaklik in eksistensiële kontekste gebruik, hoewel enkele gebruike hiervan ook in die UNI-INT-NVER-MOD-konteks voorkom (vergelyk sinne 57-65).

57 Twee spanne het gister hier sokker gespeel. (EXI-INF-PL)

58 Morsjorse het gister hier gesit en drink. (EXI-INF-NN)

59 Die klomp vrate het al die koek opgeëet voordat ek by die huis gekom het. (EXI-SPE$P L)$ 
60 Die padwerkers werk al twee weke aan die pad. (EXI-COR)

61 O gaats, die huismense het my verseker nou gehoor. (EXI-SPE-NN)

62 Alle motorbestuurders moet ten alle tye hulle sitplekgordel vasmaak. (UNI-INTNVER-MOD)

63 Die terroriste het verskeie terreuraanvalle op 'n paar plekke in die stad uitgevoer. (EXI-VAG-PL)

64 Chinese in China eet rys soos wat Suid-Afrikaners pap eet. (UNI-EXT)

65 Swernote het al die appels gepluk terwyl jy geslaap het! (EXI-VAG-NN)

Tweedens is 'n strategie aangewend om 'n uitdrukking in die imperatiewe vorm, oftewel as 'n bevelsin, uit te druk. Al 124 antwoorde is egter aangebied in die UNI-INT-NVER-MODkonteks, en die antwoorde was soortgelyk aan die sin wat in voorbeeld 47 aangebied is. Dit is dus duidelik dat die gebruik van die imperatief 'n onverpersoonlikingstrategie is wat spesifiek tot modale onpersoonlike kontekste is, en na alle waarskynlikheid beperk is tot modale kontekste wat 'n verpligting (byvoorbeeld 47), verbod (byvoorbeeld Moenie links draai by daai kruispad vandag nie), toestemming (byvoorbeeld Gooi sigaretstompies hier weg) of aanbeveling (byvoorbeeld Besoek gerus hulle webwerf) uitdruk.

'n Derde algemene onverpersoonlikingstrategie wat in ons resultate geïdentifiseer is, is om na die onpersoonlike subjek te verwys deur 'n menslike naamwoord te kies (byvoorbeeld die mense of die ou) en dan met 'n betreklike bysin te spesifiseer dat die persoon of persone relevant is tot die konteks wat beskryf word. Dit is daarom nie verrassend dat hiérdie strategie slegs in eksistensiële kontekste gebruik word nie. Die strategie is veral in die twee INFkontekste aangewend, naamlik 73 keer (vergelyk voorbeelde 66 en 67). Die strategie is egter ook 5 keer gebruik om die subjek in die EXI-COR-konteks te beskryf (byvoorbeeld 68), en telkens 'n enkele keer om die EXI-SPE-PL-, EXI-VAG-NN- en EXI-VAG-PL-kontekste se onpersoonlike subjekte te omskryf (vergelyk voorbeeldsinne 69-71).

66 Die mense wat gister hier gedrink het, het hulle gemors net hier gelos. (EXI-INF-NN)

67 Die ouens wat gister hier sokker gespeel het, het hulle bal hier vergeet. (EXI-INF$P L)$

68 Ek hoop die mense wat aan die pad werk maak gou daarmee. Dit veroorsaak te veel verkeersknope. (EXI-COR)

69 Ek gaan die ou wat al die koek opgeëet het nóú 'n koekhou slaan! (EXI-SPE-PL)

70 Hy wie al die appels gepluk het terwyl j geslaap het sal saam die vòëls 'n ander deuntjie sing. (EXI-VAG-NN)

71 Ek hoop hulle vang die mense wat die terreuraanvalle uitvoer en sit 'n bom onder hulle. (EXI-VAG-PL)

Die gebruik van die infinitiewe vorm van die werkwoord in die bysin waarin die onpersoonlike subjek voorkom, is 'n onverpersoonlikingstrategie wat in beide universele en eksistensiële kontekste gebruik word. In ons resultate is dié strategie 38 keer gebruik, naamlik 14 keer in EXI-COR-kontekste (byvoorbeeld 72), een keer in EXI-VAG-PL (byvoorbeeld 73), 16 keer in UNI-INT-NVER-MOD (byvoorbeeld 74), twee keer in UNI-EXI (byvoorbeeld 75), en vyf keer in UNI-INT-VER (byvoorbeeld 76).

72 Dink hoe gevaarlik dit is om só langs die pad te werk! (EXI-COR)

73 Blykbaar is die enigste manier om inwoners te laat hardloop is om terreuraanvalle op ' $n$ paar plekke in die stad uit te voer. (EXI-VAG-PL)

74 Dis veiliger om te ry wanneer jy jou veiligheidsgordel vasmaak. (UNI-INT-NVERMOD) 
75 Die rys prys in China is laag genoeg om heeldag dit te kan eet. (UNI-EXI)

76 In die winter is dit sleg om koud te kry. (UNI-INT-VER)

Nominalisering van die werkwoord in die bysin waarin die onpersoonlike subjek voorkom, is ook ' $n$ onverpersoonlikingstrategie wat in beide universele en eksistensiële kontekste gebruik is. In ons resultate is hiérdie strategie sewe keer in EXI-kontekste gebruik (vergelyk voorbeelde 77 tot 79), en tien keer in UNI-kontekste (vergelyk 80 tot 82)
77 Die gewerk aan die pad mors my tyd! (EXI-COR)
78 Gister was hier weer 'n groot gedrink en rinkink! (EXI-INF-NN)
79 Die uitvoer van terreuraanvalle op n paar plekke in die stad, is skrikwekkend. (EXI- $V A G-P L)$
80 Die eet van rys met amper alle maaltye in China is algemeen. (UNI-EXT)
81 Die vasmaak van jou sitplekgordel is verpligtend. (UNI-INT-NVER-MOD)
82 Die winter is vir koud kry gemaak. (UNI-INT-VER)

Die twee laasgenoemde strategieë, die gebruik van die infinitiewe vorm van die werkwoord en die nominalisering van die werkwoord, hou egter sterk met mekaar verband, aangesien dit albei strategieë is wat die niefiniete (non-finite) vorm van die werkwoord gebruik wat geen subjek neem nie (vergelyk Biber et al., 1999:125).

Twee ander strategieë wat ook met mekaar verband hou, is die kies van naamwoorde of werkwoorde wat 'n deelnemende agens impliseer (byvoorbeeld sinne 83 tot 85), en om aan 'n nielewende naamwoord die eienskap van agensskap toe te ken (wat op sigself dan ook 'n deelnemende agens impliseer, byvoorbeeld $\sin 55$ en 86). Hierdie twee strategieë word ook in beide UNI- en EXI-kontekste gebruik.

83 Daar is nog baie werk wat voorlê voor hierdie pad gebruik kan word. (EXI-COR)

84 Daar was terreuraanvalle op 'n paar plekke in die stad gewees (EXI-VAG-PL)

85 Rys is China se stapelvoedsel. (UNI-EXT)

86 Die padwerke vorder goed. Hulle werk nou al drie weke om die pad klaar te maak. $(E X I-C O R)$

Hoewel die grafiese ontwerpers wat die visuele vrae geïllustreer het, dit nié doelbewus gedoen het nie, het 'n aantal van die kontekste wat in die vraelys aangebied is, 'n negatiewe betekeniskonnotasie, soos verwyt, beskuldiging of skok (vergelyk die respondentantwoorde wat in sinne 87 tot 89 aangebied word.) Dit wil voorkom asof 'n onpersoonlike strategie wat respondente in hierdie kontekste aanwend, is om van "subjektiewe vraagwoorde" gebruik te maak om na die skuldige, dog onpersoonlike, agenssubjek te verwys. Hierdie vraagwoorde sal dan ook dikwels gekombineer word met 'n vloek- of skelwoorduitdrukking (byvoorbeeld wie die moer, wie die hel en wie de fok), of 'n beledigende naamwoord (byvoorbeeld duiwel, varke of vrate) om die subjek te beskryf. Hierdie strategie is egter beperk tot gebruik in onpersoonlike kontekste waaroor die sprekers sterk negatiewe emosies toon.

87 Watse varke het gister hier geëet en drink en alles langs die asblik gegooi? (EXI$I N F-N N)$

88 Wie de fok het al die koek opgeëet?! (EXI-SPE-PL)

89 Wie de moer het al die appels gepluk terwyl jy gelê en slaap het? (EXI-VAG-NN)

Vryekeuse-items (free choice items), oftewel VKI, is as onverpersoonlikingstrategie gebruik in 'n aantal antwoorde. Vendler (1967:80) verduidelik dat VKI aandui dat daar 'n vryheid van 
keuse vir die spreker en hoorder bestaan oor wie of wat bedoel of verstaan word, letterlik dus "no matter whom you select from among...". Daar is slegs drie onpersoonlike kontekste waarin hierdie strategie gebruik is, naamlik drie voorbeelde van EXI-INF-NN (byvoorbeeld sin 90), twee voorbeelde van EXI-INF-PL- (byvoorbeeld sin 91), en twee voorbeelde van UNI-INTNVER-MOD-kontekste (byvoorbeeld sin 94).

90 Wie ookal gister hier gesit en drink het, het 'n groot gemors agtergelaat. (EXI-INF$N N)$

91 Wie ook al gister sokker gespeel het, het hulle sokkerbal hier vergeet. (EXI-INF-PL)

92 Wie ookal gister hier sokker gespeel het, het hul bal vergeet. (EXI-INF-PL)

93 Enige iemand wat 'n motor wil bestuur, moet hul vasmaak met 'n sitplekgordel. (UNI-INT-NVER-MOD)

94 Maak nie saak wie jy is nie, maak altyd jou sitplekgordel vas! (UNI-INT-NVER-MOD)

Een van die minder algemene strategieë wat sommige respondente gebruik het in van die UNI-INT-kontekste, is om 'n naamwoord soos mense of 'n naamwoord wat 'n groep mense spesifiseer soos motorbestuurders te kwantifiseer om op so 'n wyse te spesifiseer watter persoon of persone by die konteks ingereken word. In die antwoorde op ons vraelyste is hoofsaaklik die telwoorde meeste (byvoorbeeld $\sin 95$ ), alle (byvoorbeeld sin 96) en elke (byvoorbeeld 97), gebruik, maar ander telwoorde, byvoorbeeld sommige en enkele sou ook in hierdie strategie gebruik kan word.

95 Meeste mense kry koud in die winter. (UNI-INT-VER)

96 Alle mense moet ten alle tye hulle veiligheidsgordel dra wanneer hulle bestuur. (UNI-INT-NVER-MOD)

97 Elke bestuurder moet sorg dat sy of haar sitplekgordel vasgemaak is. (UNI-INTNVER-MOD)

'n Laaste strategie wat ons raakgesien het, en waaroor ons eintlik verbaas is dat dit so min aangewend is deur die respondente, is die gebruik van die naamwoord persoon of persone om die subjek te beskryf. Gegewe die feit dat die naamwoord beteken "menslike wese, hetsy man, vrou of kind, wat nie nader bepaal of geïdentifiseer word nie" (WAT, 2020), is dit eintlik die ideale woord om te gebruik om na die onpersoonlike subjek in onpersoonlike kontekste te verwys. Nietemin is hierdie strategie slegs een keer in ons resultate aangetref (vergelyk sin 98).

98 Daar het sekerlik meer as 3 persone hier gedrink gister. (EXI-INF-NN)

\subsection{Voorkeuronverpersoonlikingstrategieë vir elke onpersoonlike konteks}

Die verskillende onverpersoonlikingstrategieë wat in elkeen van die elf onpersoonlike kontekste deur die respondente aangebied is, word in Tabel 6 opgesom.

Hoewel 'n verskeidenheid van onverpersoonlikingstrategieë in 'n verskeidenheid van onpersoonlike kontekste aangewend word, is dit opvallend dat daar wel vir sekere kontekste sterk voorkeure bestaan. In totaal is vyftien moontlike onverpersoonlikingstrategieë in ons resultate raakgesien, maar nie alle strategieë is in alle kontekste aangewend nie, en sommige strategieë is heelwat meer frekwent in sommige kontekste aangewend as in ander. 
TABEL 6: Opsomming van onverpersoonlikingstrategieë wat in elke onpersoonlike konteks gebruik is.

\begin{tabular}{|c|c|c|c|c|c|c|c|c|c|c|c|c|c|c|c|c|}
\hline & $\begin{array}{l}\mathscr{n} \\
\underline{\underline{z}} \\
\underline{\underline{z}}\end{array}$ & 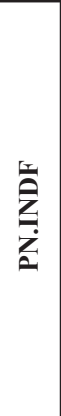 & 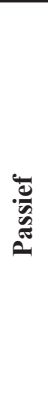 & 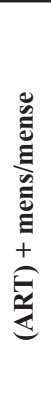 & 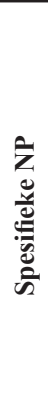 & 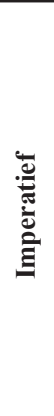 & 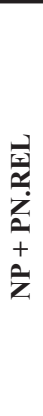 & & 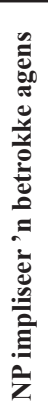 & 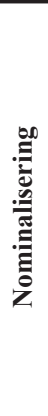 & $\frac{0}{1}$ & 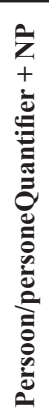 & $\bar{z}$ & 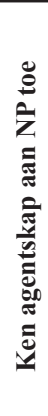 & 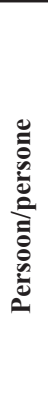 & 选 \\
\hline $\begin{array}{l}\text { UNI-INT-NVER- } \\
\text { NMOD }\end{array}$ & 302 & 6 & 26 & 47 & 0 & 0 & 0 & 0 & 0 & 0 & 0 & 0 & 0 & 1 & 0 & 382 \\
\hline $\begin{array}{l}\text { UNI-INT-NVER } \\
\text { MOD }\end{array}$ & 111 & 23 & 38 & 22 & 24 & 124 & 0 & 16 & 0 & 0 & 0 & 1 & 1 & 0 & 0 & 360 \\
\hline UNI-INT-VER & 39 & 9 & 4 & 57 & 0 & 0 & 0 & 5 & 0 & 3 & 0 & 2 & 0 & 0 & 0 & 119 \\
\hline UNI-EXT & 67 & 7 & 107 & 87 & 13 & 0 & 0 & 2 & 3 & 2 & 0 & 0 & 0 & 0 & 0 & 288 \\
\hline EXI-COR & 198 & 4 & 119 & 12 & 0 & 0 & 5 & 14 & 6 & 3 & 0 & 0 & 0 & 1 & 0 & 362 \\
\hline EXI-VAG-PL & 25 & 9 & 350 & 0 & 30 & 0 & 1 & 1 & 7 & 1 & 0 & 0 & 0 & 0 & 0 & 424 \\
\hline EXI-VAG-NN & 38 & 166 & 63 & 1 & 73 & 0 & 1 & 0 & 0 & 0 & 1 & 0 & 0 & 0 & 0 & 343 \\
\hline EXI-INF-PL & 41 & 89 & 49 & 3 & 24 & 0 & 12 & 0 & 0 & 0 & 0 & 0 & 2 & 0 & 0 & 220 \\
\hline EXI-INF-NN & 29 & 54 & 88 & 75 & 55 & 0 & 61 & 0 & 0 & 3 & 1 & 1 & 0 & 0 & 1 & 368 \\
\hline EXI-SPE-PL & 84 & 44 & 106 & 2 & 2 & 0 & 1 & 0 & 0 & 0 & 6 & 0 & 0 & 0 & 0 & 245 \\
\hline EXI-SPE-NN & 72 & 104 & 5 & 6 & 0 & 0 & 0 & 0 & 0 & 0 & 0 & 0 & 0 & 0 & 0 & 187 \\
\hline TOTAAL & 1006 & 515 & 955 & 312 & 221 & 124 & 81 & 38 & 16 & 12 & 8 & 4 & 3 & 2 & 1 & 3298 \\
\hline
\end{tabular}

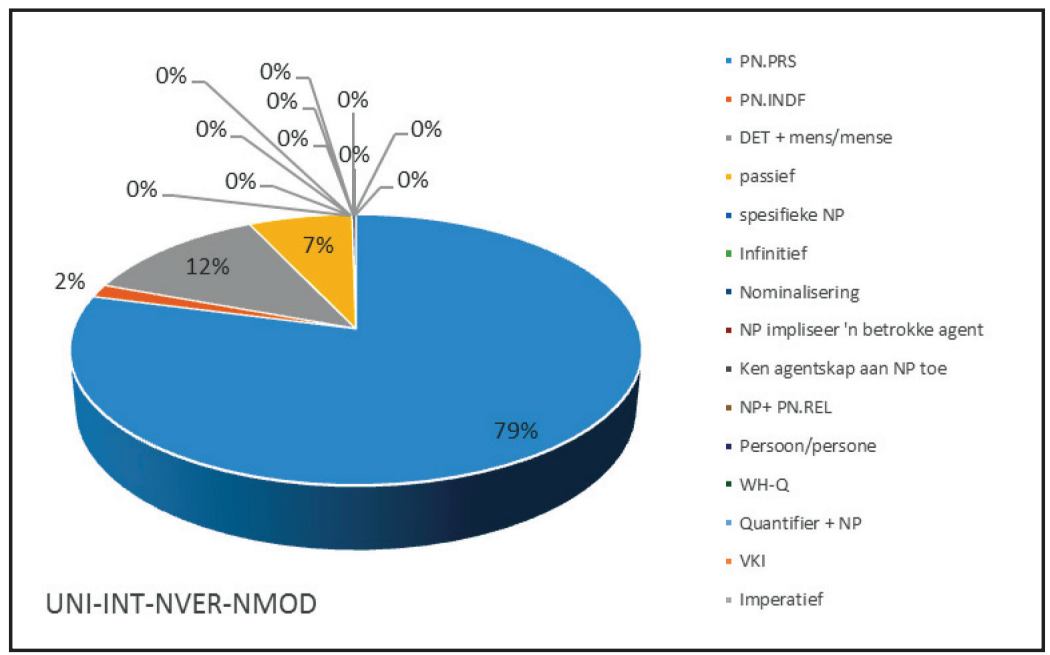

Figuur 5: $\quad$ Onverpersoonlikingstrategieë van die UNI-INT-NVERNMOD-konteks 


\subsubsection{UNI-INT-NVER-NMOD}

In die UNI-INT-NVER-NMOD-konteks is slegs vyf verskillende onverpersoonlikingstrategieë aangewend (vergelyk voorbeelde 99 tot 103), maar die persoonlike voornaamwoord is die strategie wat die meeste hier aangewend is.

99 Wat gaan gebeur indien ek hierdie knoppie druk? (PN.PRS.1.SG)

100 Wat gebeur as jy die knoppie druk? (PN.PRS.2.SG)

101 Wat sal gebeur as iemand die rooi knoppie druk? (PN.INDF)

102 Wat gebeur as mens die rooi knoppie druk? (mens)

103 Wat sal gebeur as dié knoppie gedruk word? (passief)

104 Wat doen die knoppie? (ken agensskap aan NP toe)

Die rede vir die hoë frekwensie van persoonlike voornaamwoorde kan egter ook toegeskryf word aan die feit dat dit hoofsaaklik die 1.SG-voornaamwoord is wat gebruik is om dié visuele vraag te beantwoord, en dié antwoord is - soos ons reeds verduidelik het - meerduidig, want dit kan beide 'n persoonlike en onpersoonlike interpretasie hê. Die 2.SG (vergelyk sin 100) is slegs 13 keer as antwoord aangebied, en die vraag kan daarom gevra word of die persoonlike voornaamwoord dan wérklik 'n voorkeuronverpersoonlikingstrategie vir UNI-INT-NVERNMOD-kontekste is. Dit wil dus voorkom asof Afrikaanse sprekers graag van ('n) mens en die passiefkonstruksie gebruik maak om 'n UNI-UNI-NVER-NMOD-konteks te beskryf.

\subsubsection{UNI-INT-NVER-MOD}

'n Groot verskeidenheid onverpersoonlikingstrategieë is deur respondente aangebied om die UNI-UNT-NVER-MOD-kontekste te beskryf (vergelyk 105 tot 114).

105 Jy moet jou sitplekgordel vasmaak. (PN.PRS)

106 Elkeen moet hul sitplekgordel vasmaak. (PN.INDF)

107 'n Mens moet 'n mens se sitplekgordel vasmaak. (ART+mens)

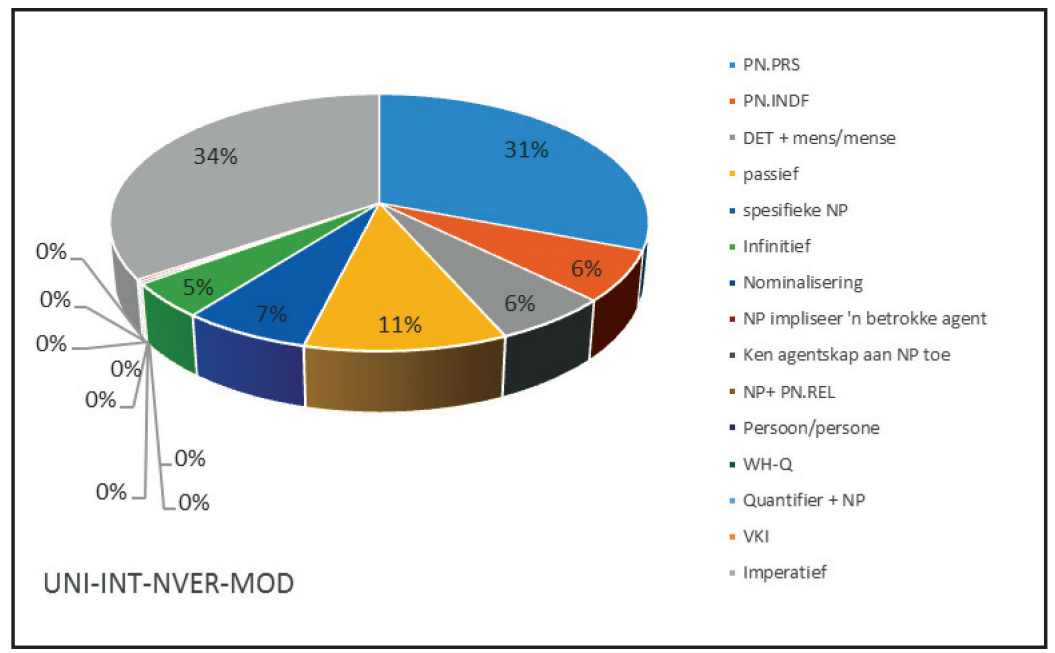

Figuur 6: Onverpersoonlikingstrategieë van die UNI-INT-NVERMOD-konteks 
108 'n Sitplekgordel moet vasgemaak word. (passief)

109 Alle bestuurders moet hulle sitplekgordel vasmaak. (spesifieke NP)

110 Onthou om altyd jou sitplekgordel vas te maak. (imperatief)

111 Dit is baie belangrik om altyd jou sitplekgordel vas te maak. (infinitief)

112 Vasmaak van 'n sitplekgordel is verpligtend. (nominalisering)

113 Alle mense moet te alle tye hulle veiligheidsgordel dra wanneer hulle bestuur. (Quantifier $+N P)$

114 Enige iemand wat 'n motor wil bestuur, moet hul vasmaak met 'n sitplekgordel. (VKI)

Veral drie onverpersoonlikingstrategieë het taamlik voorkeur geniet by respondente, naamlik persoonlike voornaamwoorde, die imperatief en die passiefkonstruksie.

Ons het egter 'n ander patroonmatige formulering van die MOD-kontekste raakgesien, naamlik dat respondente die konteks met 'n komplekse sin beskryf, waarin die modale betekenis in die hoofsin uitgedruk word, en die onverpersoonlikingstrategie in die komplementbysin (vergelyk sinne 115 en 116).

115 Die wet vereis dat jy jou sitplekgordel vasmaak.

116 Dit is belangrik dat die sitplekgordel vasgemaak word.

Altesaam twaalf respondente het die MOD-onpersoonlike konteks op hierdie manier omskryf.

\subsubsection{UNI-INT-VER}

Hoewel ten minste sewe verskillende onverpersoonlikingstrategieë aangewend is om die UNI-INT-VER-konteks te beskryf, is dit duidelik dat daar veral twee voorkeurstrategieë onder Afrikaanse respondente was, naamlik die gebruik van persoonlike voornaamwoorde en die gebruik van ('n) mens. Wat egter opmerklik is, is dat daar van meer as een persoonlike voornaamwoord gebruik is om hierdie konteks te omskryf. Dit is wel moontlik dat sommige antwoorde waarin persoonlike voornaamwoorde as 'n strategie gebruik is, 'n meerduidige (dus hetsy as persoonlik of onpersoonlik) interpretasie kan hê, maar in alle gevalle is dit wel moontlik

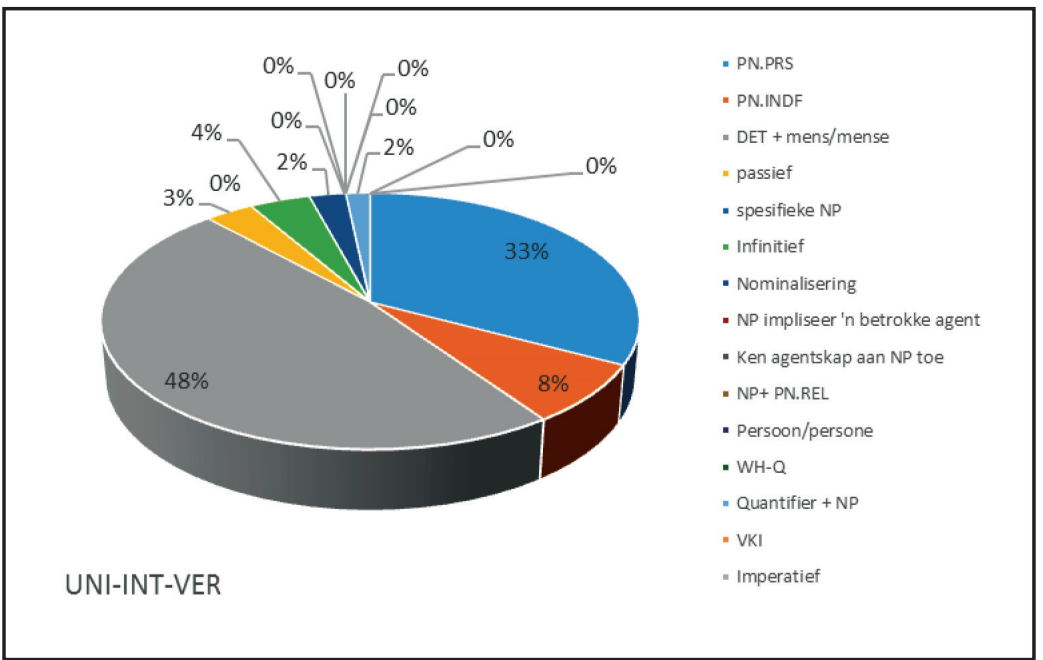

Figuur 7: Onverpersoonlikingstrategieë van die UNI-INT-VER-konteks 
om ook te kon aflei dat die spreker die voornaamwoord só gebruik het om na die hele mensdom te verwys (waarby hy of sy hom of haarself byreken).

117 In die winter kry ek koud. (PN.PRS.1.SG)

118 In die winter kry jy koud. (PN.PRS.2.SG)

119 In die winter kry ons koud.(PN.PRS.3.SG)

120 Almal kry koud in die winter! (PN.INDF)

121 Die winter sal daar koud gekry word. (passief)

122 Mens kry in die winter koud. (mens)

123 In die winter is dit sleg om koud te kry. (infinitief)

124 Die winter is vir koud kry gemaak. (nominalisering)

125 Meeste mense kry koud in die winter. (Kwantifiseerder $+N P$ )

\subsubsection{UNI-EXT}

Agt verskillende onverpersoonlikingstrategieë is gebruik om die UNI-EXT-konteks te beskryf, maar daar blyk 'n sterk voorkeurstrategie te wees vir hierdie konteks, naamlik die passiefkonstruksie..$^{10}$ Verder is ook net een persoonlike voornaamwoord hier gebruik, naamlik 3.PL, oftewel hulle.

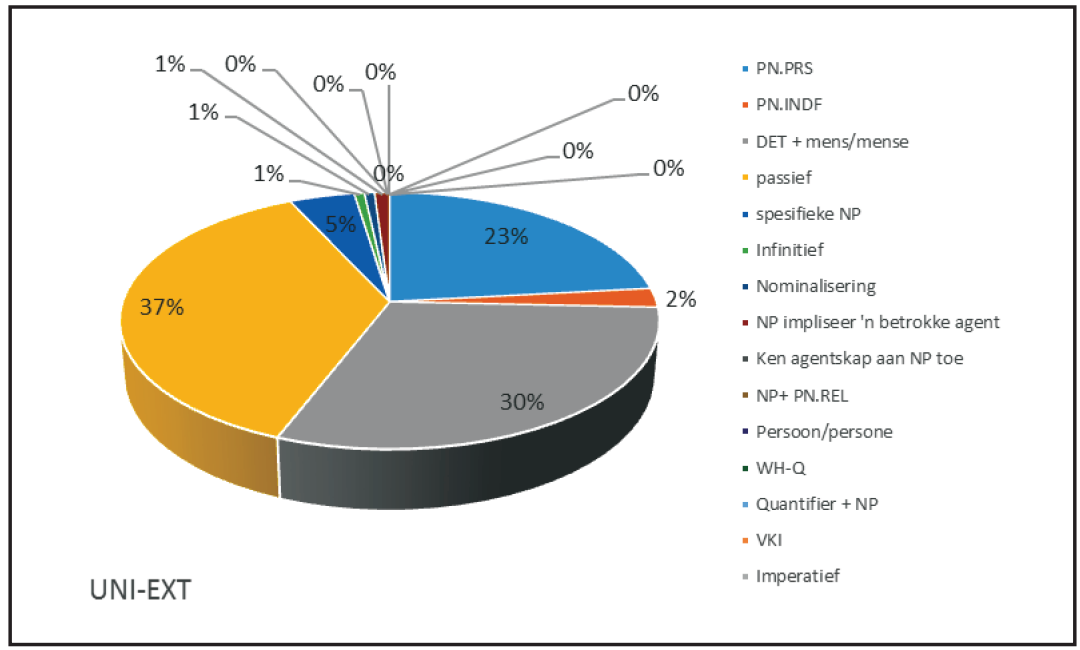

Figuur 8: $\quad$ Onverpersoonlikingstrategieë van die UNI-EXT-konteks

10 Vanweë die feit dat die agens in 'n onpersoonlike passiefkonstruksie verswyg word, is dit ook moontlik dat die respondente hulself by die konteks sou kon inreken (dus as UNI-INT). Aangesien die antwoorde wél ook die vraag beantwoord het wat ons aan die respondente gebied het, het ons die antwoorde hier gereken as 'n onpersoonlike strategie. 
126 In China eet hulle rys. (PN.PRS)

127 In China eet almal baie rys. (PN.INDF)

128 Orals in China word daar rys geëet. (passief)

129 Chinese eet baie rys. (spesifieke NP)

130 In China is dit algemeen om rys saam met die meeste etes te eet. (infinitief)

131 Rys is China se stapelvoedsel. (NP impliseer 'n betrokke agens)

132 Die eet van rys met amper alle maaltye in China is algemeen. (nominalisering)

\subsubsection{EXI-COR}

Veral twee strategieë is algemeen gebruik om die EXI-COR-konteks te beskryf, naamlik die gebruik van persoonlike voornaamwoorde (spesifiek PN.PRS.3.PL) en die passiefkonstruksie. Naas hierdie twee strategieë, het respondente ook nog sewe ander onverpersoonlikingstrategieë aangewend (vergelyk sinne 133 tot 141).

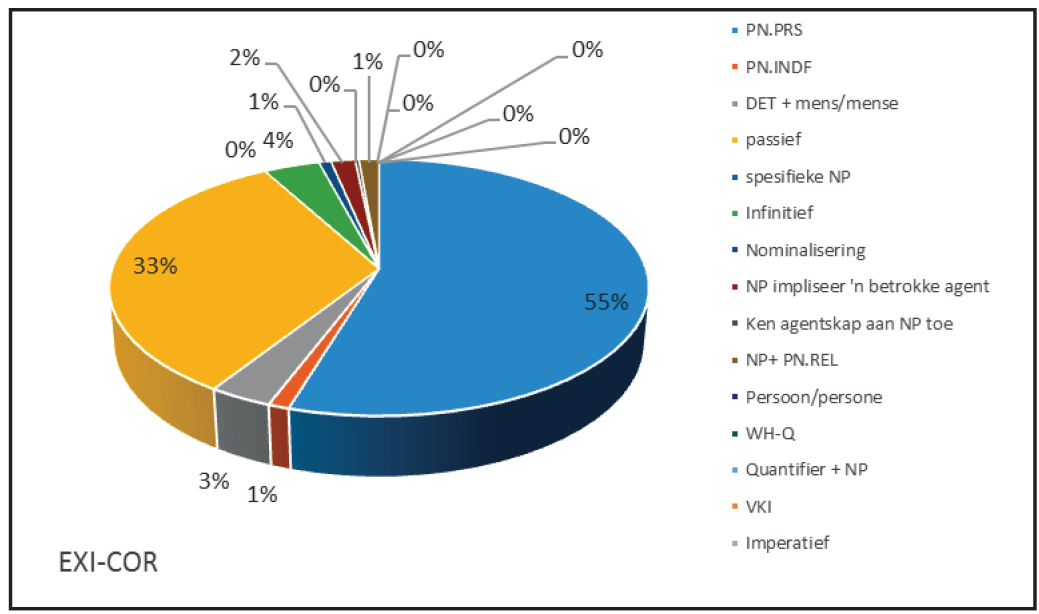

Figuur 9: $\quad$ Onverpersoonlikingstrategieë van die EXI-COR-konteks

133 Hulle werk alweer aan die pad. (PN.PRS)

134 Iemand werk daar voor in die pad. (PN.INDF)

135 Daar word aan die pad gewerk. (passief)

136 Die mense werk alweer aan die pad. (ART+mense)

137 Ek hoop die mense wat aan die pad werk maak gou daarmee. Dit veroorsaak te veel verkeersknope. $(N P+P N . R E L)$

138 Jissie, om so aan die pad te werk is harde werk. (infinitief)

139 Hoekom is daar altyd padwerke in die oggend op die pad as jy moet gaan werk? (NP impliseer 'n betrokke agens)

140 Die gewerk aan die pad mors my tyd! (nominalisering)

141 Die padwerke vorder goed. (ken agensskap aan NP toe)

Wat vir ons opmerklik was, is dat daar in hierdie konteks nie deur 'n enkele respondent gebruik gemaak is van spesifieke naamwoorde (soos padwerkers) om die situasie te beskryf nie. Selfs al het die situasie hom daartoe geleen om van hierdie strategie gebruik te maak, het respondente van ander meer eksplisiete onpersoonlike strategieë gebruik gemaak. 


\subsubsection{EXI-VAG-PL}

Die passiefkonstruksie is 'n besondere algemene onverpersoonlikingstrategie in die EXI-VAGPL-kontekste. Hoewel agt verskillende strategieë deur respondente aangebied is, is nie een van die ander strategieë werklik produktief aangewend nie. Slegs 25 respondente het byvoorbeeld van persoonlike voornaamwoorde gebruik gemaak, en slegs 30 respondente van spesifieke naamwoorde om na die onpersoonlike subjek ('n onbekende groep persone) te verwys.

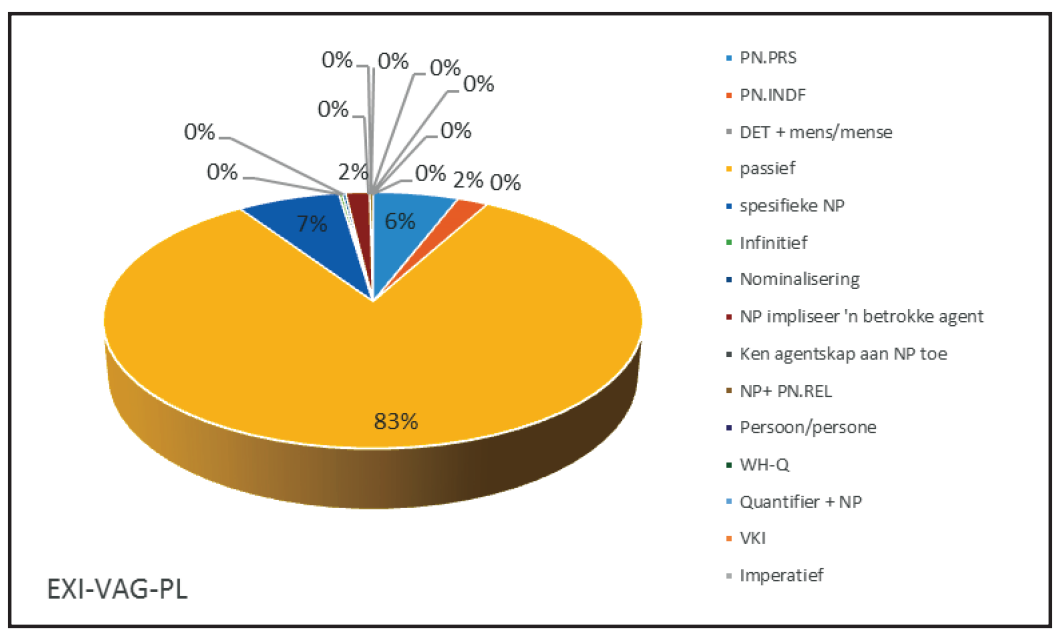

Figuur 10: $\quad$ Onverpersoonlikingstrategieë van die EXI-VAG-PL-konteks

142 Hulle het terreuraanvalle op 'n paar plekke in die stad uitgevoer. (PN.PRS)

143 Iemand het om 05 h35 drie terreuraanvalle uitgevoer in die stad. (PN.INDF)

144 Daar is al weer terreuraanvalle op 'n paar plekke in die stad uitgevoer. (passief)

145 Die terroriste het terreuraanvalle op 'n paar plekke in die stad uitgevoer. (spesifieke $N P)$

146 Ek hoop hulle vang die mense wat die terreuraanvalle uitvoer en sit 'n bom onder hulle. $(N P+P N . R E L)$

147 Blykbaar is die enigste manier om inwoners te laat hardloop is om terreuraanvalle op 'n paar plekke in die stad uit te voer. (infinitief)

148 Die terreuraanvalle het op 'n paar plekke in die stad plaasgevind! (NP impliseer 'n betrokke agens)

149 Die uitvoer van terreuraanvalle op 'n paar plekke in die stad, is skrikwekkend. (nominalisering)

\subsubsection{EXI-VAG-NN}

Onbepaalde voornaamwoorde (spesifiek die voornaamwoord iemand) is die voorkeurstrategie vir EXI-VAG-NN-kontekste. Ook die passiefkonstruksie en spesifieke naamwoorde is strategieë wat gereeld deur respondente gebruik is om hierdie konteks te beskryf. 
150 Hulle het al die appels gepluk terwyl jy geslaap het. (PN.PRS)

151 Iemand het al die appels gepluk terwyl jy geslaap het! (PN.INDF)

152 Terwyl jy geslaap het, is al die appels gepluk. (passief)

153 Die mense het al die appels gepluk terwyl jy geslaap het! (ART+mense)

154 Diewe het al die appels gepluk terwyl jy geslaap het. (spesifieke NP)

155 Hy wie al die appels gepluk het terwyl jy geslaap het sal saam die vöels $n$ ander deuntjie sing. (NP+PN.REL)

156 Wie de moer het al die appels gepluk gepluk terwyl jy gelê en slaap het? (WH-Q)

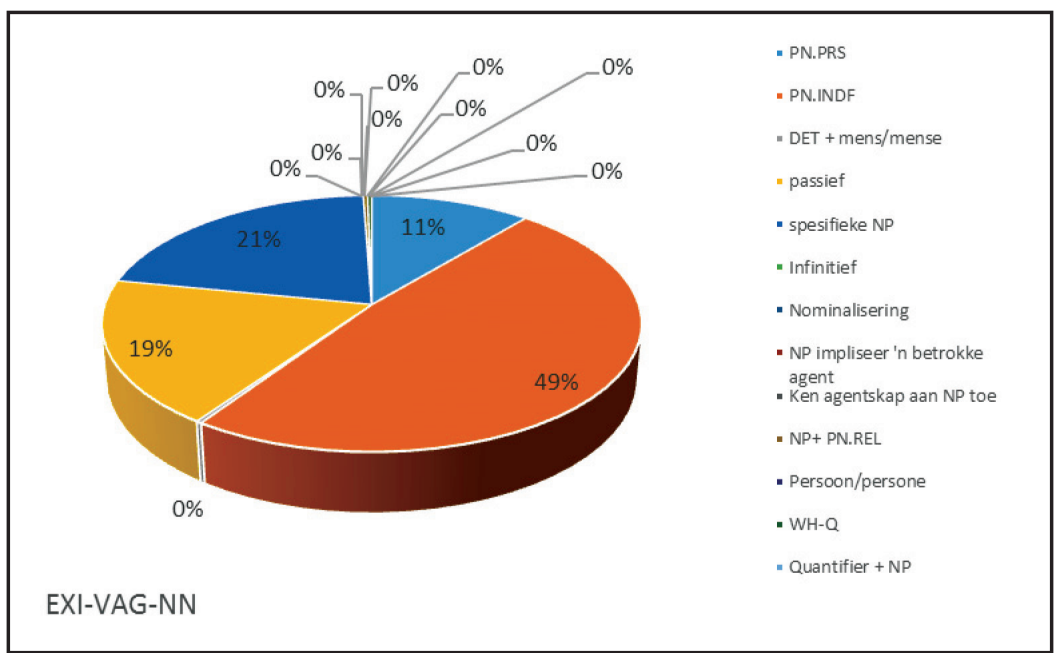

Figuur 11: Onverpersoonlikingstrategieë van die EXI-VAG-NN-konteks

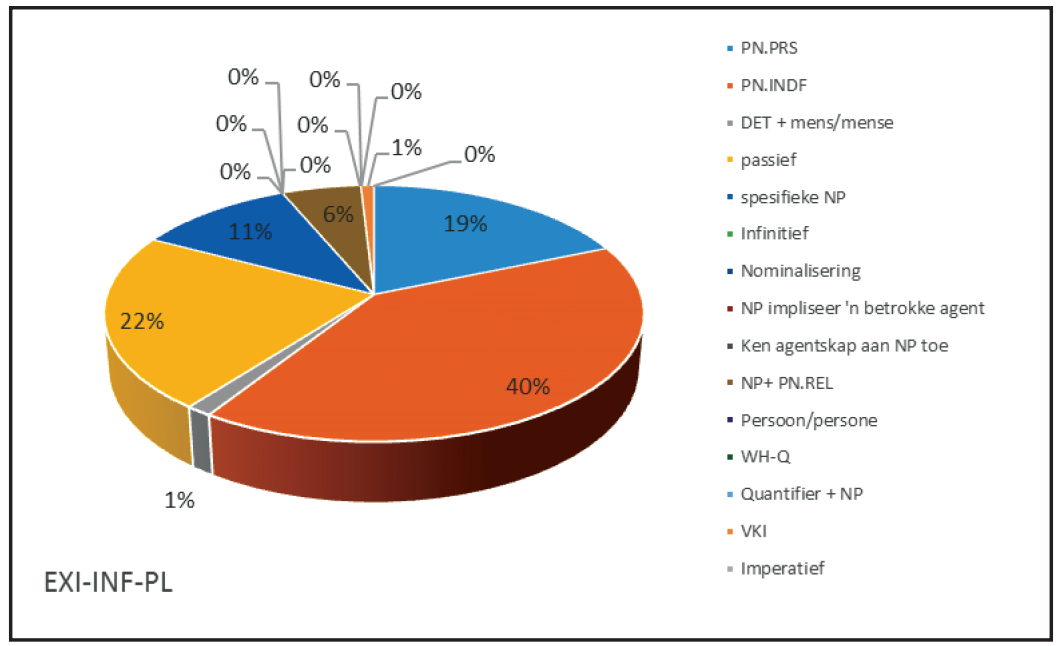

Figuur 12: $\quad$ Onverpersoonlikingstrategieë van die EXI-INF-PL-konteks 


\subsubsection{EXI-INF-PL}

Sewe verskillende onverpersoonlikingstrategieë is deur respondente gebruik om die EXI-INFPL-konteks te beskryf. Veral drie strategieë is deur heelwat respondente gebruik, naamlik persoonlike voornaamwoorde, onbepaalde voornaamwoorde en die passiefkonstruksie. Meer as 20 respondente het ook spesifieke naamwoorde gebruik om na die niereferensiële groep persone te verwys.

157 Hulle het gister hier sokker gespeel. (PN.PRS)

158 Ek sien iemand het gister hier sokker gespeel. (PN.IDF)

159 Hier was gister sokker gespeel. (passief)

160 Gister het mense hier sokker gespeel. (mense)

161 Twee spanne het gister hier sokker gespeel. (spesifieke NP)

162 Die bal behoort aan die span wat gister hier sokker gespeel het. (NP+PN.REL)

163 Wie ook al gister sokker gespeel het, het hulle sokkerbal hier vergeet. (VKI)

\subsubsection{EXI-INF-NN}

'n Hele aantal onverpersoonlikingstrategieë is produktief in die EXI-INF-NN-konteks aangewend. In totaal is tien verskillende strategieë in hierdie konteks aangewend, met die passief en mense as die mees frekwente strategieë. Die rede hiervoor is waarskynlik omdat alle getalneutrale kontekste óók as meervoud geïnterpreteer kan word, en derhalwe is mense 'n geskikte strategie.

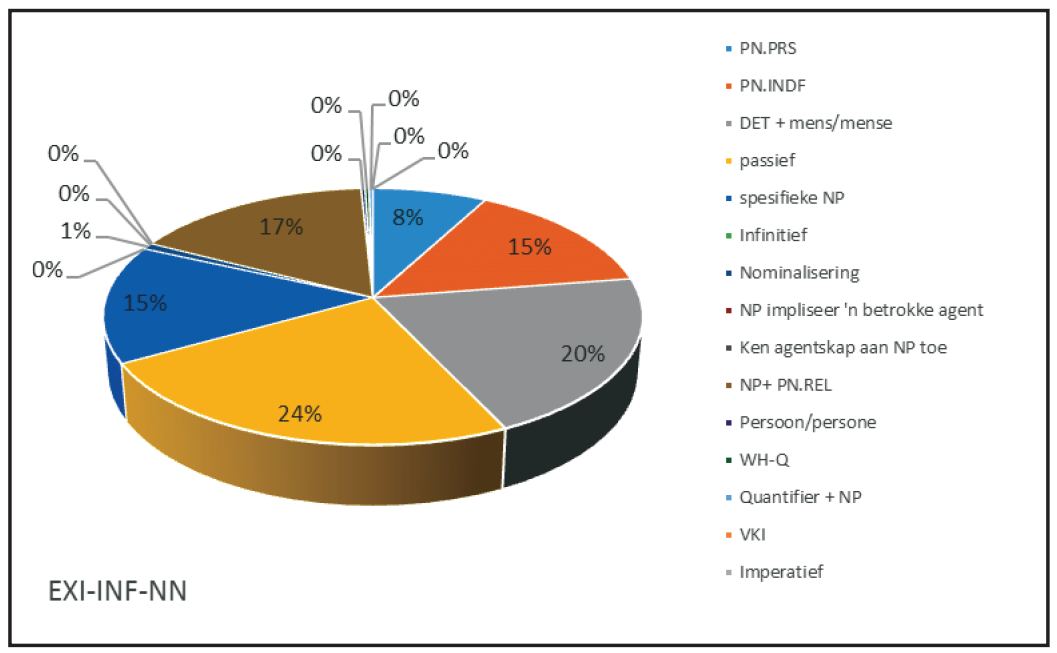

Figuur 13: Onverpersoonlikingstrategieë van die EXI-INF-NN-konteks

164 Hulle het duidelik gister hier gedrink. (PN.PRS)

165 Iemand het gister vreeslik hier gedrink. (PN.INDF)

166 Hier is gister groot gedrink. (passief)

167 Mense het gister hier baie gedrink. (mense)

168 Daar het 'n klomp morsjorse gister hier sit en drink. (spesifieke NP)

169 Kom ons tel die mense wat gister hier gedrink het se gemors op. (NP+PN.REL) 
170 Gister was hier weer 'n groot gedrink en rinkink! (nominalisering)

171 Watse varke het gister hier geëet en drink en alles langs die asblik gegooi. (WH-Q)

172 Een of ander vent het gister hier gedrink (Kwantifiseerder $+N P$ )

173 Daar het sekerlik meer as 3 persone hier gedrink gister. (persoon)

\subsubsection{EXI-SPE-PL}

Ook in die EXI-SPE-PL-kontekste ${ }^{11}$ is die passief die voorkeur onverpersoonlikingstrategie, maar die twee voornaamwoordelike strategieë is ook gereeld deur respondente gebruik. Sewe verskillende strategieë is deur respondente gebruik om hierdie konteks te beskryf.

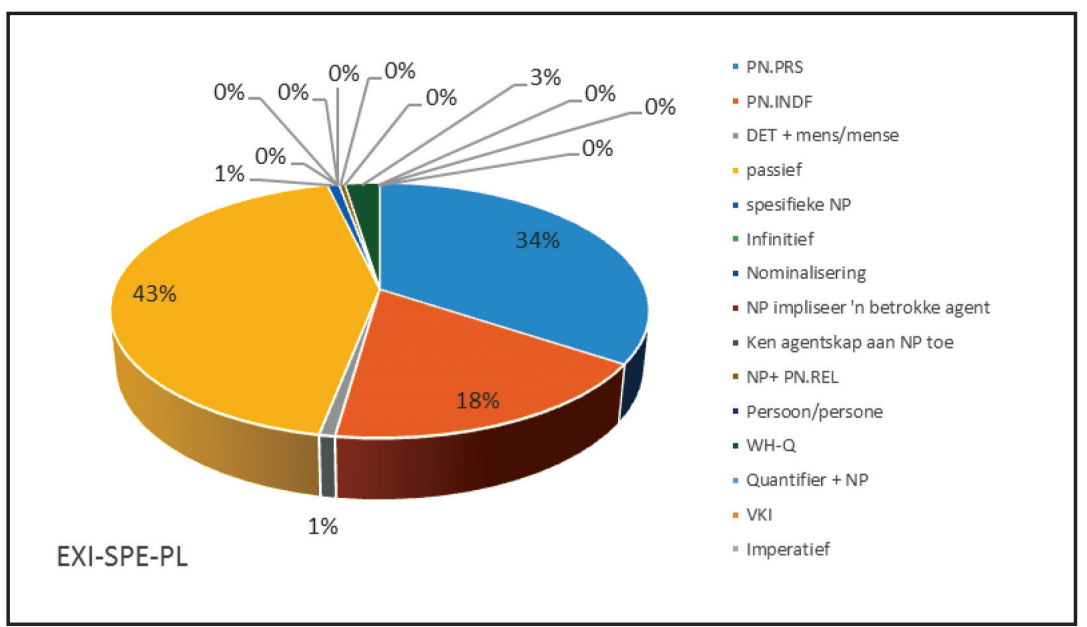

Figuur 14: Onverpersoonlikingstrategieë van die EXI-SPE-PL-konteks

174 Hulle het wragtig al die koek opgeëet! (PN.PRS)

175 Iemand het sowaar al die koek opgeëet! (PN.INDF)

176 Al die koek is opgeëet! (passief)

177 Die mense het al die koek opgeëet! (ART+mense)

178 Die klomp vrate het al die koek opgeëet voordat ek by die huis gekom het. (spesifieke $N P)$

179 Ek gaan die ou wat al die koek opgeëet het nóú 'n koekhou slaan! (NP+PN.REL)

180 Wie der duiwel het al die koek opgeëet! (WH-Q)

11 Vanuit die antwoorde wat deur die respondente aangebied is, is ons nie heeltemal seker of die respondente die konteks as EXI-SPE-PL- of as EXI-VAG/INF geïnterpreteer het nie. Ons is egter van mening dat die resultate vir ons insigte bied oor die wyse waarop Afrikaanse sprekers 'n SPE-konteks sou kon beantwoord, en derhalwe interpreteer ons die antwoorde van dié konteks, soos aangebied deur die respondente. 


\subsubsection{EXI-SPE-NN}

Slegs vier onverpersoonlikingstrategieë is gebruik om die EXI-SPE-NN-konteks te beskryf, en die twee voornaamwoordelike strategieë is die algemeenste. Enkele respondente het ook van 'n passiefkonstruksie en mense gebruik gemaak as 'n strategie.

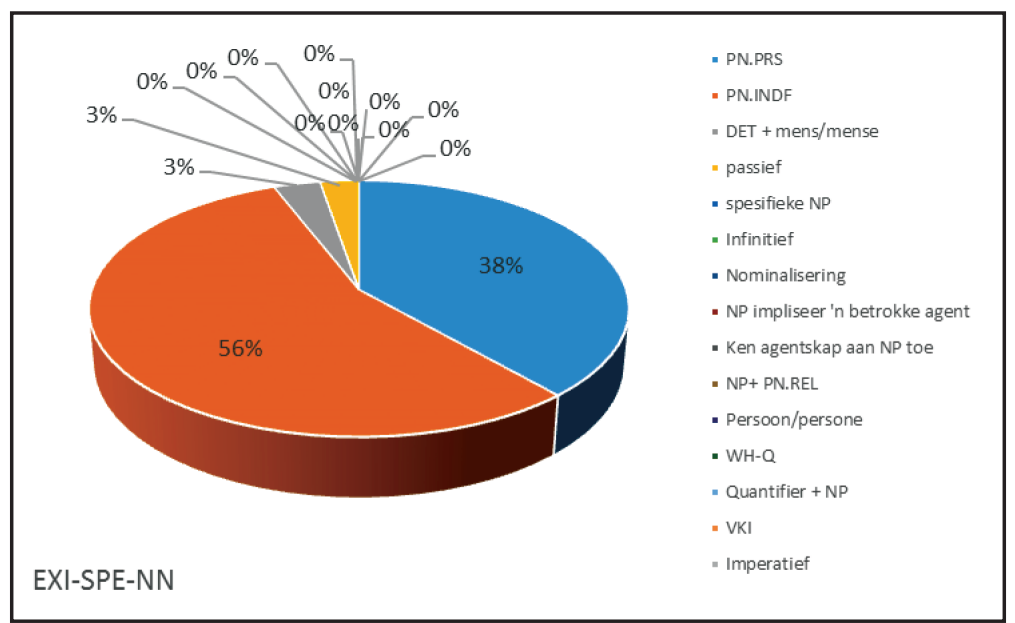

Figuur 15: Onverpersoonlikingstrategieë van die EXI-SPE-NNkonteks

181 Hulle het my gehoor! (PN.PRS)

182 Iemand het dit gehoor! (PN.INDF)

183 'n Geluid is gehoor (passief)

184 Nou het die mense my beslis gehoor! (ART+mense)

\section{Samevatting}

Die doel van hierdie artikel was om eerstens te bepaal watter moontlike onverpersoonlikingstrategieë deur Afrikaanse sprekers aangewend word om onpersoonlike kontekste te beskryf, en tweedens te sien of daar bepaalde voorkeure vir sprekers bestaan oor watter strategieë om te gebruik in verskillende en onderskeibare onpersoonlike kontekste.

Die resultate van die visuele vraelys het dit wél moontlik gemaak om 'n verskeidenheid moontlike onverpersoonlikingstrategieë te identifiseer. In vorige literatuur oor onverpersoonlikingstrategieë in Afrikaans (maar ook Wes-Germaans) is slegs vier strategieë aangebied as moontlike maniere waarop sprekers kontekste as onpersoonlik beskryf. Die resultate van ons vraelyste het ons egter gewys dat daar meerdere strategieë tot Afrikaanssprekers se beskikking is, en in totaal is daar van vyftien onderskeibare onverpersoonlikingstrategieë gebruik gemaak om die kontekste in ons vraelys te beskryf. Die vraelys sou volgens ons ook bruikbaar kan wees om 'n verskeidenheid onverpersoonlikingstrategieë in ander tale te kan identifiseer en op kontrastiewe wyse die resultate van die verskillende tale met mekaar te kan vergelyk, om sodoende die lys van moontlike onverpersoonlikingstrategieë in Wes-Germaans aan te vul. 
Die resultate het ook 'n aantal voorkeurstrategieë aangedui vir elke onderskeibare onpersoonlike konteks. Drie strategieë is bruikbaar in álle onpersoonlike kontekste, naamlik die gebruik van persoonlike voornaamwoorde, onbepaalde voornaamwoorde en die passief. Verder is die naamwoordstukke, naamlik ('n) mens en (die) mense, ook strategieë wat gereeld aangewend word, hoewel nie in VAG-kontekste nie, ook tot 'n mindere mate in die SPE-kontekste.

\section{BIBLIOGRAFIE}

Arif, MM \& Hashim, F. 2008. Reading from the Wordless: A Case Study on the Use of Wordless Picture Books. English Language Teaching, 1(1):121-126.

Botha, WF (red.). 2019. e-WAT: elektroniese woordeboek van die Afrikaanse taal. http://www.woordeboek. co.za.nwulib.nwu.ac.za/ [19 Oktober 2019].

Breed, A \& Van Olmen, D. 2017. Menslike onpersoonlike voornaamwoorde in Nederlands vanuit 'n dubbelvraelysaanpak - 'n vergelyking met Afrikaans. Tydskrif vir Nederlands en Afrikaans, 2017(2): 3-38.

Breed, A \& Van Olmen, D. 2021. The passive as an impersonalisation strategy in Afrikaans and Dutch: A corpus investigation. Dutch Crossing, 45(2):171-207.

Breed, A, Chan, JA \& Van Olmen, D. 2021. Developing and validating a visual questionnaire for the study of impersonalisation strategies: A design thinking approach. Southern African Linguistics and Applied Language Studies, 39(2):152-176.

Coussé, E \& van der Auwera, J. 2012. Human impersonal pronouns in Swedish and Dutch: A contrastive study of man and men. Languages in Contrast,12:121-138.

Deringer, L, Gast, V, Haas, F \& Rudolf, O. 2015. Human impersonal pronouns in populist discourse. Invited talk at workshop "Interdisciplinary perspectives on populist discourse in Germany and Poland", August 20-21, 2015. Institut für Anglistik/Amerikanistik, Friedrich-Schiller-Universität Jena. https://scholar.google.com/scholar?hl=nl\&as_sdt $=0 \% 2 \mathrm{C} 5 \& \mathrm{q}=\% 22$ human + impersonal + pro nouns $\% 22+$ haas\&btnG $=[20$ Oktober 2020].

Egerland, V. 2003. Impersonal Pronouns in Scandinavian and Romance. Working Papers in Scandinavian Syntax. Department of Scandinavian Languages, Lund University, pp. 75-102.

Fouché, N \& Kapp, S. 2020. Persoonlike voornaamwoorde. Taalonderrigportaal. Die Virtuele Instituut vir Afrikaans (VivA). https://viva-afrikaans.org/portale/taalonderrigportaal?link=Afdeling-Woord soorte\%2FVoornaamwoord\%2FAAG_Woordsoort_PN_Soorte_Persoonlik.html. [20 Oktober 2020].

Garcia, B, Sallandre, M \& L'Huillier, M. 2018. Impersonal human reference in French Sign Language (LSF). Sign Language and Linguistics, 21(2):307-333.

Gast, V \& van der Auwera, J. 2013. Towards a distributional typology of human impersonal pronouns, based on data from European languages. In Bakker \& Haspelmath (eds). Languages Across Boundaries: Studies in the Memory of Anna Siewierska. Berlin: Mouton de Gruyter, pp. 119-158.

Groenen, G. 2021. Hoe onpersoonlijk is persoonlijk?: Een contrastief corpusonderzoek van de Afrikaanse en Nederlandse persoonlijke voornaamwoorden jy/je en hulle/ze. Potchefstroom: NoorwesUniversiteit. [MA-verhandeling].

Hoekstra, J. 2010. On the impersonal pronoun men in Modern West Frisian. The Journal of Comparative Germanic Linguistics, 13(1):31-59.

Horwat, J. 2018. Too subtle for words: doing wordless narrative research. Art/Research International: A Transdisciplinary Journal, 3(2):172-195.

Kirsten, J. 2016. Grammatikale Verandering in Afrikaans van 1911-2010. Vanderbijlpark: North-West University.[ PhD-proefskrif].

Kitagawa, C \& Lehrer, A. 1990. Impersonal uses of personal pronouns. Journal of Pragmatics, 14(5):739759.

Luukka, M \& Markkanen, R. 1997. Impersonalisation as a form of hedging. In Markkanen \& Schröder (eds). Hedging and Discourse: Approaches to the Analysis of a Pragmatic Phenomenon in Academic, Research in Text Theory. Berlin: De Gruyter, pp. 168-187.

Malamud, SA. 2012. Impersonal Indexicals: One, You, Man, and Du. The Journal of Comparative Germanic Linguistics, 15(1):1-48. 
Malchukov, AL \& Siewierska, A. 2015. Impersonal Constructions: A cross-linguistic perspective. Amsterdam: John Benjamins.

Marin-Arrese, EM, Neff, J, Pérez de Ayala Becerril, S, Gómez, MLB \& Ávila, CM. 2001. A corpus study of impersonalisation strategies in newspaper discourse in English and Spanish. In Rayson, Wilson, McEnery, Hardie \& Khoja (eds). Proceedings of the Corpus linguistics 2001 Conference, 29 March - 2 April 2001, Lancaster, UK. University Centre for Computer Corpus Research on Language. Lancaster: UCREL, 13:369-377.

Nodelman, P. 1990. Words about pictures. Georgia: University of Georgia Press.

Pharos. 2006. "Onpersoonlik”. Sinonieme en verwante woorde. Kaapstad: NB Uitgewers.

Rudolf, O. 2014. A Corpus-Based Study of Human Impersonal Constructions in Russian, In Witkos \& Sylwester (eds). New Insights into Slavic Linguistics-Series Title Sprachund Kulturkontakte in Europas Mitte. Bern: Peter Lang, pp. 329-343.

Siewierska, A\& Papastathi, M. 2011. Towards a typology of third personal plural impersonals. Linguistics, 49(3):575-610.

Siewierska, A. 2008. Ways of impersonalising: Pronominal vs verbal strategies. In de los Ángeles Gómez, Maria, Mackenzie \& González Álvarez (eds). Current Trends in Contrastive Linguistics: Functional and cognitive perspectives. Amsterdam: John Benjamins, pp. 3-26.

Siewierska, A. 2011. Overlap and complementarity in reference impersonals: Man-constructions vs. third person plural-impersonal in the languages of Europe. In Malchukov \& Siewierska (eds). Impersonal Constructions: A Cross-Linguistic Perspective. Amsterdam: John Benjamins, pp. 57-89.

Van der Auwera, J, Gast, V \& Vanderbiesen, J. 2012. Human impersonal pronouns in English, Dutch and German. Leuvense Bijdragen, 98(1):27-64.

Van Olmen, D \& Breed, A. 2018a. Human impersonal pronouns in Afrikaans: A double questionnairebased study. Language Sciences, 69:1-29, September. https://doi.org/10.1016/j.langsci.2018.05.002 [20 Oktober 2020]

Van Olmen, D \& Breed, A. 2018b. Human impersonal pronouns in West Germanic: A questionnairebased comparative study of Afrikaans, Dutch and English. Studies in Language, 42(4):798-846

Van Olmen, D, Breed, A \& Verhoeven, B. 2019. A corpus-based study of the human impersonal pronoun ('n) mens in Afrikaans. Languages in Contrast, 19(1): 9-105. https://doi.org/10.1075/lic.17004.van [19 Oktober 2020]

Vendler, Z. 1967. Linguistics in Philosophy. Ithaca: Cornell University Press

Virtuele Instituut vir Afrikaans (VivA). 2020. Korpusportaal: Omvattend 1.7. http://viva-afrikaans.org. [19 Oktober 2020].

Zobel, S. 2015. A pragmatic analysis of German impersonally used first person singular 'ICH'. In: The referential ambiguity of personal pronouns and its pragmatic consequences. De Cock \& Kluge (eds). Pragmatics, 26(3):379-416. 